\title{
ПРОБЛЕМЫ РУДНОЙ ГЕОЛОГИИ И ЧЕЛОВЕЧЕСКИЙ ФАКТОР. ЧАСТЬ 4. МЕТАМОРФИЗМ И МЕЗОТЕРМАЛЬНОЕ РУДООБРАЗОВАНИЕ
}

\author{
Кучеренко Игорь Васильевич, \\ kivr@tpu.ru \\ Национальный исследовательский Томский политехнический университет, \\ Россия, 634050, г. Томск, пр. Ленина, 30.
} Актуальность. Условия образования известных многочисленных мезотермальных месторождений золота в толщах черных
сланцев разного возраста составляют предмет оживленной дискуссии, которая нередко приобретаетчерты суррогатной и, веро-
ятно, в силу этого бесконечной вследствие исключения конкретным автором или авторским коллективом из учета, анализа,
обобщения, обсуждения фактов, важных для решения проблемы, но не вписывающихся в доказательную базу данных разраба-
тываемых им/ими представлений.

Цель: для получения корректных результатов, необходимых для углубления теории гидротермального рудообразования и разработки, совершенствования комплексов эффективных прогнозно-поисковых критериев оруденения, устранять это негативное проявление человеческого фактора и в процедуре реконструкции процессов рудообразования вернуть дискуссию в нормальное русло посредством включения в научный оборот «удобных» и «неудобных» фактов.

Методы. Выполнен анализ баз данных, предложенных давно и недавно в обоснование метаморфогенно-гидротемальной и других гипотез образования мезотермальных месторождений золота в толщах черных сланцев. Обсуждаются приведенные авторские материалы, в том числе аналитические данные - результаты полного химического силикатного анализа (мокрого) горных пород, атомно-абсорбционного анализа содержания золота, серебра, ртути в горных породах, петрохимических балансовых расчетов межзональной миграции петрогенных элементов в околорудных метасоматических ореолах, математической обработки содержаний в горных породах рудогенных элементов.

Результаты. Сделан вывод о геолого-генетической однородности мезотермальных месторождений золота, образованных в кристаллическом и черносланцевом субстрате. Доказательством этому служат следующие ключевые факты: 1) контроль месторождений глубинными разломами; 2) близкий геологический возраст ранних плутонов, массивов палингенных гранитоидов С многочисленными сопровождающими дайками средне-кислых пород и поздними дайками умеренно-щелочных долеритов, долеритов, лейкодолеритов дорудных, внутрирудных, послерудных генераций, в том числе преобразованными в высокотемпературные биотит-роговообманковые метасоматиты внутрирудными дайками-флюидопроводниками, и руд; 3) аутентичная минералого-петрохимическая зональность околорудных метасоматических ореолов в том и другом субстрате, образованных в условиях калиево-сернисто-углекислотного метасоматизма пропилит-березитового профиля с поступлением в ореолы калия, восстановленной серы, углекислоты, удалением натрия и частично кремния; 4) наследование околорудными метасоматитами петрохимического профиля внутридолеритового метасоматизма и контрастных аномалий фемофильных элементов (P, Mg, Fe, Ti); 5) отвечающие метеоритному стандарту (мантии) изотопные отношения серы сульфидов и углерода карбонатов руд и околорудных метасоматитов. Перечисленные факты исключают участие метаморфизма в рудообразовании. В Ленском районе, как и в других золоторудных районах горно-складчатого обрамления Сибирского кратона, мезотермальные месторождения золота образованы в составе антидромных гранит-диорит-долеритовых флюидно-рудно-магматических комплексов на позднем базитовом этапе их функционирования, а внутрирудные дайки-флюидопроводники преобразованных в высокотемпературные биотит-роговообманковые метасоматиты умеренно щелочных долеритов служат связующим звеном между базитовыми очагами мантии - источниками золотоносных растворов - и месторождениями золота в коре.

Структура статьи. В части 3 статьи приведены разделы: содержание проблем и постановка задачи; минералого-петрохимическая зональность околорудных метасоматических ореолов пропилит-березитового профиля в мезотермальных месторождениях золота, образованных в кристаллическом субстрате и толщах черных сланцев; минералого-петрохимическая зональность околорудного метасоматического ореола золоторудного месторождения Сухой Лог. В части 4 статьи приведены разделы: распределение рудогенных элементов в околорудном пространстве мезотермальных месторождений золота, образованных в кристаллическом субстрате и толщах черных сланцев; обсуждение результатов и выводы; заключение.

\section{Ключевые слова:}

Мезотермальные месторождения золота, кристаллический субстрат, черные сланцы, магматизм, метаморфизм, рудообразование, человеческий фактор.

Распределение рудогенных элементов в околорудном пространстве мезотермальных месторождений золота, образованных

в кристаллическом субстрате и толщах черных сланцев

Распределение рудогенных (золота, серебра, ртути), как и петрогенных, включая фемофильные, элементов в рудовмещающих горных породах разных состава, возраста и происхождения в мезотермальных месторождениях золота подчиняется околорудной метасоматической (минералого-петрохимической) зональности (табл. $1-4$, рис. 1,2 ).
Это выражается в субкларковых содержаниях металлов во фронтальной зоне околорудных метасоматических ореолов или в повышенных против кларка, но минимальных во вскрытых объемах ореолов содержаниях их, - при недоступности для изучения фронтальной зоны в промежуточных хлоритовой, углеродистой минералого-петрохимических зонах и в повышении содержаний металлов в направлении к тыловым (альбитовой, березитовой) зонам с достижением, как правило, в последней максимальных значений. Также последова- 
тельно возрастают, за редкими исключениями, другие параметры распределения металлов - стандартный множитель, стандартное отклонение содержаний, золото-серебряное отношение - максимальные в тыловых зонах. Перечисленные макси- мальные значения параметров распределения сочетаются с максимальными доверительными интервалами изменения средних геометрических содержаний металлов в метасоматитах тыловых зон (рис. 1, 2).

Таблица 1. Оиенка паралетров распределения рудогенных элементов в минералого-петрохимических зонах околорудных (рудовлещающих) метасоматических ореолов золоторудных месторождений юго-восточного складчатого обралления Сибирского кратона

Table 1. Appraisal of parameters of oregenous elements distribution in mineral-petrochemic zones of mesothermal goldore deposits nearore (orecontaining) metasomatic haloes in south-eastern folded frame of Siberian craton

\begin{tabular}{|c|c|c|c|c|c|c|c|}
\hline \multirow{4}{*}{ 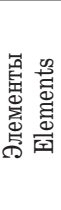 } & \multirow{4}{*}{$\begin{array}{c}\text { Параметры } \\
\text { распределения } \\
\text { Distribution } \\
\text { parameters }\end{array}$} & \multicolumn{6}{|c|}{$\begin{array}{l}\text { Минералого-петрохимические зоны и подзоны [число проб] } \\
\text { Mineral-Petrochemic zones and subzones [number of samples] }\end{array}$} \\
\hline & & \multicolumn{3}{|c|}{ Фронтальная/Frontal } & \multirow{3}{*}{$\begin{array}{c}\text { Хлоритовая } \\
\text { Chloritic }\end{array}$} & \multirow{3}{*}{$\begin{array}{l}\text { Альбитовая } \\
\text { Albitic }\end{array}$} & \multirow{3}{*}{$\begin{array}{l}\text { Тыловая } \\
\text { Rear }\end{array}$} \\
\hline & & \multicolumn{3}{|c|}{ Подзоны/Subzones } & & & \\
\hline & & $\begin{array}{l}\text { Слабого изменения } \\
\text { Weak alteration }\end{array}$ & $\begin{array}{l}\text { Умеренного изменения } \\
\text { Moderate alteration }\end{array}$ & $\begin{array}{l}\text { Интенсивного изменения } \\
\text { Intensive alteration }\end{array}$ & & & \\
\hline \multicolumn{8}{|c|}{ I. Ирокиндинское месторождение/Irokindinskoe deposit Кальцифиры $\left(\mathrm{AR}_{2}\right) /$ Calciphyres $\left(\mathrm{AR}_{2}\right)$} \\
\hline \multirow{2}{*}{$\mathrm{Au}$} & $\overline{x z}(\bar{x})$ & $0,9(1,2)[25]$ & $0,9(1,4)[23]$ & $0,9(1,0)[6]$ & $1,0(1,2)[7]$ & $1,7(5,7)[18]$ & $7,2(188,0)[53]$ \\
\hline & $t(s)$ & $2,1(1,7)$ & $2,3(1,9)$ & $1,8(0,6)$ & $1,7(0,6)$ & $4,0(12,1)$ & $8,4(982,7)$ \\
\hline \multirow{4}{*}{$\mathrm{Ag}$} & $\overline{x z}(\bar{x})$ & $42,5(53,4)$ & $30,9(36,1)$ & $44,4(47,6)$ & $52,0(70,8)$ & $175,6(399,7)$ & $112,0(242,0)$ \\
\hline & $t(s)$ & $2,2(32,1)$ & $1,9(20,2)$ & $1,5(20,8)$ & $2,8(46,8)$ & $3,7(603,3)$ & $3,5(408,0)$ \\
\hline & $r(s r)(\mathrm{Au}-\mathrm{Ag})$ & $0,75(0,17)$ & $0,09(0,37)$ & $0,80(0,16)$ & $0,03(0,50)$ & $0,91(0,05)$ & $0,47(0,16)$ \\
\hline & $\mathrm{Au} / \mathrm{Ag}$ & 0,02 & 0,03 & 0,02 & 0,02 & 0,01 & 0,06 \\
\hline \multirow{3}{*}{$\mathrm{Hg}$} & $\overline{x_{2}}(\bar{x})$ & $23,8(29,6)$ & $21,6(32,4)$ & $32,5(39,6)$ & $23,4(30,3)$ & $27,0(48,8)$ & $41,7(64,7)$ \\
\hline & $t(s)$ & $2,0(19,9)$ & $2,3(35,3)$ & $2,1(25,5)$ & $2,2(24,2)$ & $3,1(56,4)$ & $2,7(63,6)$ \\
\hline & $r(s r)(\mathrm{Au}-\mathrm{Hg})$ & $-0,36(0,33)$ & $-0,54(0,27)$ & $-0,06(0,45)$ & $0,47(0,39)$ & $0,0002(0,29)$ & $0,24(0,19)$ \\
\hline \multicolumn{8}{|c|}{ Альмандин-диопсид-двуполевошпатовые гнейсы $\left(\mathrm{AR}_{2}\right) /$ Almandine-diopside-twofeldspathic gneisses $\left(\mathrm{AR}_{2}\right)$} \\
\hline \multirow{2}{*}{$\mathrm{Au}$} & $\overline{x z}(\bar{x})$ & $0,7(1,1)[29]$ & $0,6(0,7)[48]$ & $0,7(0,7)[29]$ & \begin{tabular}{|l|}
$0,7(0,8)[23]$ \\
\end{tabular} & $16,5(47,0)[65]$ & $49,9(228,8)[169]$ \\
\hline & $t(s)$ & $2,1(1,8)$ & $1,5(0,3)$ & $1,5(0,3)$ & $1,4(0,3)$ & $4,0(94,0)$ & $5,7(646,0)$ \\
\hline \multirow{4}{*}{$\mathrm{Ag}$} & $\overline{x z}(\bar{x})$ & $35,7(43,9)$ & $50,0(55,9)$ & $60,3(85,3)$ & $56,8(92,7)$ & $153,1(222,0)$ & $134,3(268,1)$ \\
\hline & $t(s)$ & $1,8(36,8)$ & $1,7(25,3)$ & $2,2(95,1)$ & $3,2(109,8)$ & $2,3(239,8)$ & $2,9(590,8)$ \\
\hline & $r(s r)(\mathrm{Au}-\mathrm{Ag})$ & $0,73(0,12)$ & $0,02(0,20)$ & $0,38(0,22)$ & $0,68(0,14)$ & $0,82(0,06)$ & $0,50(0,12)$ \\
\hline & $\mathrm{Au} / \mathrm{Ag}$ & 0,02 & 0,01 & 0,01 & 0,01 & 0,1 & 0,37 \\
\hline \multirow{3}{*}{$\mathrm{Hg}$} & $\overline{x_{2}}(\bar{x})$ & $17,1(22,0)$ & $15,6(18,2)$ & $19,3(34,4)$ & $21,7(34,8)$ & $19,7(33,4)$ & $28,7(55,2)$ \\
\hline & $t(s)$ & $2,0(17,0)$ & $1,7(11,5)$ & $2,4(56,5)$ & $2,3(53,8)$ & $2,6(47,0)$ & $2,9(99,4)$ \\
\hline & $r(s r)(\mathrm{Au}-\mathrm{Hg})$ & $-0,07(0,19)$ & $-0,36(0,13)$ & $-0,10(0,18)$ & $0,04(0,27)$ & $0,05(0,11)$ & $0,07(0,08)$ \\
\hline \multicolumn{8}{|c|}{ Альмандин-двуслюдяные гнейсы $\left(\mathrm{AR}_{2}\right) /$ Almandine-twomica gneisses $\left(\mathrm{AR}_{2}\right)$} \\
\hline \multirow{2}{*}{$\mathrm{Au}$} & $\overline{x z}(\bar{x})$ & $0,5(0,6)[30]$ & $1,2(1,4)[17]$ & $1,9(2,5)[15]$ & $1,7(2,4)[96]$ & $2,3(4,1)[24]$ & $11,5(1439,5)[34]$ \\
\hline & $t(s)$ & $1,3(0,2)$ & $1,7(0,7)$ & $2,4(1,7)$ & $2,3(2,4)$ & $2,3(8,5)$ & $21,0(1220,0)$ \\
\hline & $\overline{x z}(\bar{x})$ & $36,2(43,1)$ & $33,3(42,4)$ & $42,5(52,4)$ & $38,9(56,0)$ & $76,5(91,1)$ & $160,2(777,8)$ \\
\hline$\Delta x$ & $t(s)$ & $2,2(19,3)$ & $2,3(25,9)$ & $2,0(32,5)$ & $2,5(50,3)$ & $1,9(50,2)$ & 4,0 (н/д) \\
\hline Ag & $r(s r) \mathrm{Au}-\mathrm{Ag})$ & $0,12(0,33)$ & $0,61(0,19)$ & $-0,32(0,26)$ & $0,42(0,20)$ & $0,09(0,23)$ & $0,72(0,12)$ \\
\hline & $\mathrm{Au} / \mathrm{Ag}$ & 0,01 & 0,04 & 0,04 & 0,05 & 0,03 & 0,08 \\
\hline & $\overline{x z}(\bar{x})$ & $19,4(21,4)$ & $21,2(23,4)$ & $17,0(19,7)$ & $18,3(20,8)$ & $15,0(19,9)$ & $18,3(26,4)$ \\
\hline $\mathrm{Hg}$ & $t(s)$ & $1,6(9,5)$ & $1,6(10,0)$ & $1,7(11,8)$ & $1,6(12,5)$ & $2,2(16,3)$ & $2,1(33,2)$ \\
\hline & $r(s r)(\mathrm{Au}-\mathrm{Hg})$ & $-0,46(0,26)$ & $-0,23(0,29)$ & $0,19(0,28)$ & $0,33(0,22)$ & $-0,33(0,20)$ & $0,14(0,25)$ \\
\hline & & Гранит & матитовой выплавки & $\left.{ }_{2}\right) /$ Granites of migmatiti & melting $\left(\mathrm{AR}_{2}\right)$ & & \\
\hline$A_{11}$ & $\overline{x z}(\bar{x})$ & $0,6(0,7)[28]$ & $0,6(0,7)[10]$ & $0,6(0,7)[17]$ & $1,5(1,7)[49]$ & $6,4(23,2)[99]$ & $50,7(335,2)[24]$ \\
\hline $\mathrm{Au}$ & $t(s)$ & $1,6(0,4)$ & $1,4(0,2)$ & $1,4(0,2)$ & $1,8(0,9)$ & $4,9(45,7)$ & $10,6(688,3)$ \\
\hline & $\overline{x z}(\bar{x})$ & $47,9(70,3)$ & $58,9(77,2)$ & $47,3(54,8)$ & $19,0(26,1)$ & $96,8(122,9)$ & $158,5(318,5)$ \\
\hline & $t(s)$ & $2,4(71,6)$ & $2,4(50,2)$ & $1,8(27,3)$ & $2,3(19,8)$ & $2,2(78,2)$ & $3,1(513,4)$ \\
\hline Ag & $r(s r)(\mathrm{Au}-\mathrm{Ag})$ & $0,18(0,27)$ & $-0,08(0,35)$ & $0,28(0,28)$ & $-0,37(0,22)$ & $0,40(0,15)$ & $0,81(0,10)$ \\
\hline & $\mathrm{Au} / \mathrm{Ag}$ & 0,01 & 0,01 & 0,01 & 0,07 & 0,06 & 0,32 \\
\hline & $\overline{x z}(\bar{x})$ & $20,6(24,1)$ & $21,8(28,3)$ & $16,2(30,1)$ & $17,1(19,6)$ & $27,8(41,0)$ & $34,5(41,1)$ \\
\hline $\mathrm{Hg}$ & $t(s)$ & $1,7(16,6)$ & $2,2(20,9)$ & $2,5(55,1)$ & $1,7(11,8)$ & $2,4(45,9)$ & $2,0(22,0)$ \\
\hline & $r(s r)(\mathrm{Au}-\mathrm{Hg})$ & $-0,15(0,27)$ & $-0,58(0,24)$ & $-0,20(0,29)$ & $0,49(0,20)$ & $0,14(0,18)$ & $0,02(0,23)$ \\
\hline & & Микрогранит-п & ры фельзитовые дайк & $\left(\mathrm{PZ}_{3}\right) /$ Microgranite-par & yres felsitic dil & $\operatorname{kes}\left(\mathrm{PZ}_{3}\right)$ & \\
\hline$A_{11}$ & $\overline{x z}(\bar{x})$ & Н/д & H/д & $1,2(1,4)[6]$ & \begin{tabular}{|l|}
$1,4(1,9)[37]$ \\
\end{tabular} & $3,6(17,4)[120]$ & $43,1(269,5)[64]$ \\
\hline $\mathrm{Au}$ & $t(s)$ & н/д & Н/д & $1,8(1,0)$ & $2,0(1,8)$ & $4,9(53,8)$ & $9,0(736,4)$ \\
\hline & $\overline{x z}(\bar{x})$ & Н/д & н/д & $24,4(24,6)$ & н/д & $132,7(168,4)$ & $143,8(164,3)$ \\
\hline As & $t(s)$ & Н/д & Н/д & $1,1(3,0)$ & н/д & $1,8(160,0)$ & $1,7(92,9)$ \\
\hline $\mathrm{Ag}^{\prime}$ & $r(s r)(\mathrm{Au}-\mathrm{Ag})$ & $\mathrm{H} /$ д & Н/д & $0,48(0,34)$ & H/д & $\mathrm{H} / \mathrm{A}$ & н/д \\
\hline & $\mathrm{Au} / \mathrm{Ag}$ & Н/д & $\mathrm{H} /$ д & 0,05 & Н/Д & 0,03 & 0,3 \\
\hline & $\overline{x z}(\bar{x})$ & Н/д & н/д & н/д & $22,3(29,0)$ & $38,2(54,0)$ & $43,8(62,4)$ \\
\hline $\mathrm{Hg}$ & $t(s)$ & н/д & H/д & н/д & $2,0(26,2)$ & $2,4(44,7)$ & $2,2(68,7)$ \\
\hline & $r(s r)(\mathrm{Au}-\mathrm{Hg})$ & Н/Д & H/д & н/д & $0,07(0,21)$ & $0,43(0,23)$ & $0,15(0,15)$ \\
\hline
\end{tabular}


Table 1

\begin{tabular}{|c|c|c|c|c|c|c|c|}
\hline \multirow{4}{*}{ 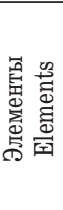 } & \multirow{4}{*}{$\begin{array}{c}\text { Параметры } \\
\text { распределения } \\
\text { Distribution } \\
\text { parameters }\end{array}$} & \multicolumn{6}{|c|}{$\begin{array}{l}\text { Минералого-петрохимические зоны и подзоны [число проб] } \\
\text { Mineral-Petrochemic zones and subzones [number of samples] }\end{array}$} \\
\hline & & \multicolumn{3}{|c|}{ Фронтальная/Frontal } & \multirow{3}{*}{$\begin{array}{l}\text { Хлоритовая } \\
\text { Chloritic }\end{array}$} & \multirow{3}{*}{$\begin{array}{l}\text { Альбитовая } \\
\text { Albitic }\end{array}$} & \multirow{3}{*}{$\begin{array}{l}\text { Тыловая } \\
\text { Rear }\end{array}$} \\
\hline & & \multicolumn{3}{|c|}{ Подзоны/Subzones } & & & \\
\hline & & $\begin{array}{l}\text { Слабого изменения } \\
\text { Weak alteration }\end{array}$ & $\begin{array}{l}\text { Умеренного изменения } \\
\text { Moderate alteration }\end{array}$ & $\begin{array}{l}\text { Интенсивного изменения } \\
\text { Intensive alteration }\end{array}$ & & & \\
\hline \multicolumn{8}{|c|}{$\begin{array}{c}\text { II. Кедровское месторождение/Kedrovskoe deposit } \\
\text { Кварцевые диориты очагово-купольной постройки }\left(\mathrm{PZ}_{3}\right) / \text { Quartz diorites of hearth-dome structure }\left(\mathrm{PZ}_{3}\right)\end{array}$} \\
\hline \multirow{2}{*}{$\mathrm{Au}$} & $\overline{x_{2}}(\bar{x})$ & $0,7(0,8)[25]$ & $0,7(0,8)[25]$ & $0,8(1,0)[6]$ & $1,4(1,7)[17]$ & $1,5(2,3)[20]$ & $3,6(3,8)[6]$ \\
\hline & $t(s)$ & $1,4(0,4)$ & $1,4(0,4)$ & $2,1(1,1)$ & $1,8(1,1)$ & $2,6(2,4)$ & $1,5(1,4)$ \\
\hline \multirow{4}{*}{$\mathrm{Ag}$} & $\overline{x_{2}}(\bar{x})$ & $19,8(26,0)$ & $19,8(26,0)$ & $27,1(28,7)$ & $34,0(33,6)$ & $24,7(36,8)$ & $46,4(47,2)$ \\
\hline & $t(s)$ & $1,9(27,0)$ & $1,9(27,0)$ & $1,4(11,9)$ & $2,4(75,6)$ & $2,5(36,3)$ & $1,2(9,2)$ \\
\hline & $r(s r)(\mathrm{Au}-\mathrm{Ag})$ & $0,55(0,16)$ & $0,55(0,16)$ & $0,93(0,05)$ & $0,16(0,24)$ & $0,35(0,21)$ & $0,69(0,21)$ \\
\hline & $\mathrm{Au} / \mathrm{Ag}$ & 0,03 & 0,03 & 0,03 & 0,04 & 0,06 & 0,08 \\
\hline \multirow{3}{*}{$\mathrm{Hg}$} & $\overline{x z}(\bar{x})$ & $18,0(19,3)$ & $18,0(19,3)$ & $24,2(29,3)$ & $17,3(17,8)$ & $19,6(32,2)$ & $25,7(39,3)$ \\
\hline & $t(s)$ & $1,5(7,9)$ & $1,5(7,9)$ & $2,0(19,5)$ & $1,3(4,6)$ & $2,3(53,2)$ & $2,7(38,4)$ \\
\hline & $r(s r)(\mathrm{Au}-\mathrm{Hg})$ & $-0,15(0,23)$ & $-0,15(0,23)$ & $-0,41(0,34)$ & $-0,04(0,24)$ & $0,13(0,23)$ & $0,94(0,05)$ \\
\hline \multicolumn{8}{|c|}{$\begin{array}{l}\text { Углеродистые мусковит-биотитовые полевошпат-кварцевые песчано-алевросланцы кедровской свиты }\left(\mathrm{R}_{3}\right) \\
\text { Carbonaceous muscovite-biotitic feldspar-quartz sandstone-aleuroslates of kedrovskaja suite }\left(\mathrm{R}_{3}\right)\end{array}$} \\
\hline \multirow{2}{*}{$\mathrm{Au}$} & $\overline{x_{2}}(\bar{x})$ & $1,2(1,6)[37]$ & $0,7(1,5)[15]$ & $1,1(1,7)[23]$ & $1,8(2,6)[123]$ & $3,9(6,9)[209]$ & $5,8(15,3)[27]$ \\
\hline & $t(s)$ & $2,1(1,5)$ & $2,9(2,7)$ & $2,7(1,6)$ & $2,0(4,0)$ & $2,8(9,5)$ & $4,5(19,9)$ \\
\hline \multirow{4}{*}{$\mathrm{Ag}$} & $\overline{x_{2}}(\bar{x})$ & $26,7(32,1)$ & $23,3(26,0)$ & $56,6(91,7)$ & $61,7(165,1)$ & $135,8(223,4)$ & $165,0(278,5)$ \\
\hline & $t(s)$ & $1,9(20,9)$ & $1,6(13,9)$ & $2,6(116,6)$ & $4,6(340,4)$ & $2,6(359,5)$ & $3,1(257,0)$ \\
\hline & $r(s r)(\mathrm{Au}-\mathrm{Ag})$ & $0,001(0,2)$ & $0,79(0,11)$ & $0,22(0,21)$ & $0,21(0,12)$ & $0,11(0,09)$ & $0,44(0,16)$ \\
\hline & $\mathrm{Au} / \mathrm{Ag}$ & 0,04 & 0,03 & 0,02 & 0,03 & 0,03 & 0,04 \\
\hline \multirow{3}{*}{$\mathrm{Hg}$} & $\overline{x z}(\bar{x})$ & $18,0(26,3)$ & $28,3(34,7)$ & $22,0(30,4)$ & $24,5(34,1)$ & $17,5(23,5)$ & $30,5(36,0)$ \\
\hline & $t(s)$ & $2,8(20,7)$ & $2,1(18,7)$ & $2,2(27,0)$ & $2,4(30,1)$ & $2,1(20,6)$ & $1,8(21,4)$ \\
\hline & $r(s r)(\mathrm{Au}-\mathrm{Hg})$ & $0,35(0,16)$ & $0,50(0,22)$ & $0,20(0,21)$ & $-0,15(0,12)$ & $-0,11(0,08)$ & $0,58(0,13)$ \\
\hline \multicolumn{8}{|c|}{$\begin{array}{l}\text { III. Каралонское месторождение/Karalonskoe deposit } \\
\text { Углеродистые мусковит-биотитовые полевошпат-кварцевые песчано-алевросланцы водораздельной свиты }\left(\mathrm{R}_{3}\right) \\
\text { Carbonaceous muscovite-biotitic feldspar-quartz sandstone-aleuroslates of vodorazdelnaja suite }\left(\mathrm{R}_{3}\right)\end{array}$} \\
\hline \multirow{2}{*}{$\mathrm{Au}$} & $\overline{x_{2}}(\bar{x})$ & $1,0(1,1)[15]$ & Н/Д & $1,6(2,0)[11]$ & $2,0(2,8)[34]$ & $2,0(3,5)[7]$ & $24,7(73,5)[6]$ \\
\hline & $t(s)$ & $1,6(0,4)$ & Н/д & $1,9(1,8)$ & $2,4(2,6)$ & $2,8(5,1)$ & $5,6(100,9)$ \\
\hline \multirow{4}{*}{$\mathrm{Ag}$} & $\overline{x z}(\bar{x})$ & $25,1(35,1)$ & Н/Д & $34,9(64,7)$ & $45,6(65,1)$ & $29,4(44,5)$ & $53,3(60,2)$ \\
\hline & $t(s)$ & $2,2(34,8)$ & $\mathrm{H} / \mathrm{A}$ & $2,9(99,3)$ & $2,4(75,0)$ & $2,9(39,9)$ & $1,8(29,6)$ \\
\hline & $r(s r)(\mathrm{Au}-\mathrm{Ag})$ & $0,56(0,18)$ & Н/д & $0,73(0,14)$ & $0,52(0,12)$ & $0,80(0,13)$ & $0,70(0,21)$ \\
\hline & $\mathrm{Au} / \mathrm{Ag}$ & 0,04 & н/д & 0,04 & 0,04 & 0,07 & 0,4 \\
\hline \multirow{3}{*}{$\mathrm{Hg}$} & $\overline{x z}(\bar{x})$ & $32,4(37,3)$ & Н/д & $47,0(49,0)$ & $58,0(68,6)$ & $42,2(61,6)$ & $44,6(46,5)$ \\
\hline & $t(s)$ & $1,8(19,2)$ & Н/Д & $1,4(14,8)$ & $1,7(61,4)$ & $2,5(63,5)$ & $1,4(16,3)$ \\
\hline & $r(s r)(\mathrm{Au}-\mathrm{Hg})$ & $0,12(0,25)$ & Н/Д & $-0,007(0,30)$ & $-0,22(0,16)$ & $0,55(0,26)$ & $-0,30(0,37)$ \\
\hline \multicolumn{8}{|c|}{$\begin{array}{c}\text { IV. Ирокиндинский прогиб/Irokindinskii trough } \\
\text { Углеродистые мусковит-биотитовые алевро-пелитосланцы мухтунной свиты }\left(\mathrm{R}_{3}\right) \\
\text { Carbonaceous muscovite-biotitic aleuro-pelitoslates of muhtunnaja suite }\left(\mathrm{R}_{3}\right)\end{array}$} \\
\hline \multirow{2}{*}{$\mathrm{Au}$} & $\overline{x_{2}}(\bar{x})$ & н/д & Н/Д & Н/д & $0,6(0,6)[39]$ & $0,6(0,7)[24]$ & $1,0[1]$ \\
\hline & $t(s)$ & н/д & Н/Д & Н/Д & $1,6(0,3)$ & $1,6(0,5)$ & Н/д \\
\hline \multirow{4}{*}{$\mathrm{Ag}$} & $\overline{x z}(\bar{x})$ & н/д & Н/д & Н/Д & $14,7(16,2)$ & $19,8(25,7)$ & 19,0 \\
\hline & $t(s)$ & н/д & н/д & Н/д & $1,6(7,1)$ & $2,1(19,0)$ & Н/Д \\
\hline & $r(s r)(\mathrm{Au}-\mathrm{Ag})$ & Н/д & Н/Д & Н/Д & $0,27(0,15)$ & $0,53(0,15)$ & Н/д \\
\hline & $\mathrm{Au} / \mathrm{Ag}$ & Н/д & Н/Д & Н/Д & 0,04 & 0,03 & Н/Д \\
\hline & $\overline{x z}(\bar{x})$ & н/д & $\mathrm{H} / \mathrm{A}$ & Н/д & $15,1(17,8)$ & $16,6(18,1)$ & 12,5 \\
\hline $\mathrm{Hg}$ & $t(s)$ & H/Д & Н/Д & Н/Д & $1,8(10,4)$ & $1,5(7,9)$ & Н/Д \\
\hline & $r(s r)(\mathrm{Au}-\mathrm{Hg})$ & н/д & н/д & Н/д & Н/д & н/д & Н/д \\
\hline
\end{tabular}

Примечание. Здесь и в табл. 2-5: 1) $\overline{x 2}(\bar{x})$ - среднее соответственно геометрическое и арифметическое содержание, мг/т; $t$ - стандартный множитель; $s$ - стандартное отклонение содержаний, мг/m; $r$ - коэффициент парной линейной корреляции элелентов с золотом, выше уровня значимости обозначен жирныл шрифтом; sr - стандартное отклонение коэффициента корреляции; н/д - нет данных. 2 ) В квадратных скобках - число проб. 3 ) Содержание Аи и Ag определялось атомно-абсорбиионнылм методом (чувствительность 0,1 мг/m) в лаборатории ядерно-физических методов анализа вещества ОИГГиМ СО РАН (г. Новосибирск), аналитик В.Г. Цимбалист. Содержание $\mathrm{Hg}$ определялось атомно-абсорбиионным методом (чувствительность 5 мг/m) в Цл ПГО «Березовгеология» (г. Новосибирск) под руководством Н.А. Чарикова. 4) Расчеты выполнены Н.П. Ореховым.

Note. Here and in the tables 2-5:1) $\overline{x z}(\bar{x})$ are the moderate geometric and arithmetic content accordingly, mg/t; $t$ is the standard multiplytion; $s$ is the standard digression of the contents, $\mathrm{mg} / \mathrm{t} ; \mathrm{r}$ is of couple linear correlation elements coefficient with gold, higher than the significance level is designated by bold type; sr is the standard digression of the correlation coefficient; $н / \partial-$ no data. 2) In square brackets - the number of samples. 3) The content of Au and Ag were determined by means of atomic-absorption method (the revelation limit is $0,1 \mathrm{mg} / \mathrm{t}$ ) in the laboratory of Siberian Section RAS Institute Geology, Geophysics and Mineralogy (Novosibirsk) by guidance of V.G. Tsimbalist, the content of Hg - by means of atomic-absorption method (the revelation limit is $5 \mathrm{mg} / \mathrm{t}$ ) in the laboratory of Bereozovgeology (Novosibirsk) by guidance of N.A. Charikov. 4) The calculations were fulfilled by N.P. Orekhov. 

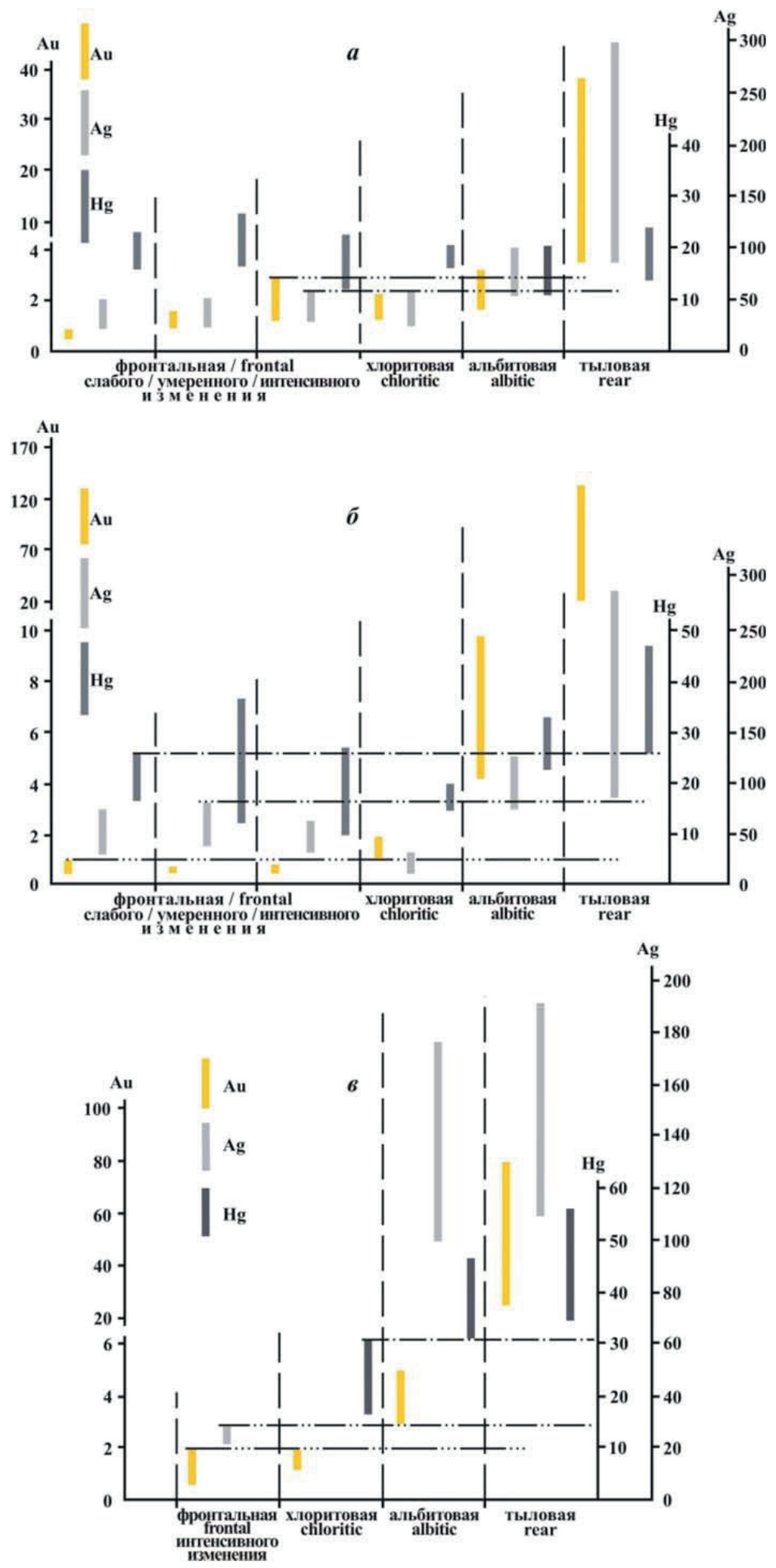

Рис. 1. Доверительные интервалы изленений среднего геолетрического содержания золота, серебра, ртути (мг/m) в линералого-петрохимических зонах околорудных метасоматических ореолов, образованных в альмандин-двуслюдяном гнейсе (а), граните мигматитовой выплавки (б), дайках фельзитовых микрогранит-порфиров (в) Ирокиндинского месторождения (при 5 \% уровне значимости)

Fig. 1. Trust (ing) alteration intervals of average geometric content of gold, silver, mercury ( $\mathrm{mg} / \mathrm{t}$ ) in mineral-petrochemic zones of nearore metasomatic haloes formed in almandine-twomica gneisses (a), granite migmatitic melting (б), felsitic microgranite-porphyre dikes ( 8 ) of Irokindinskoe deposit (attached to 5 per cent level of significance) 

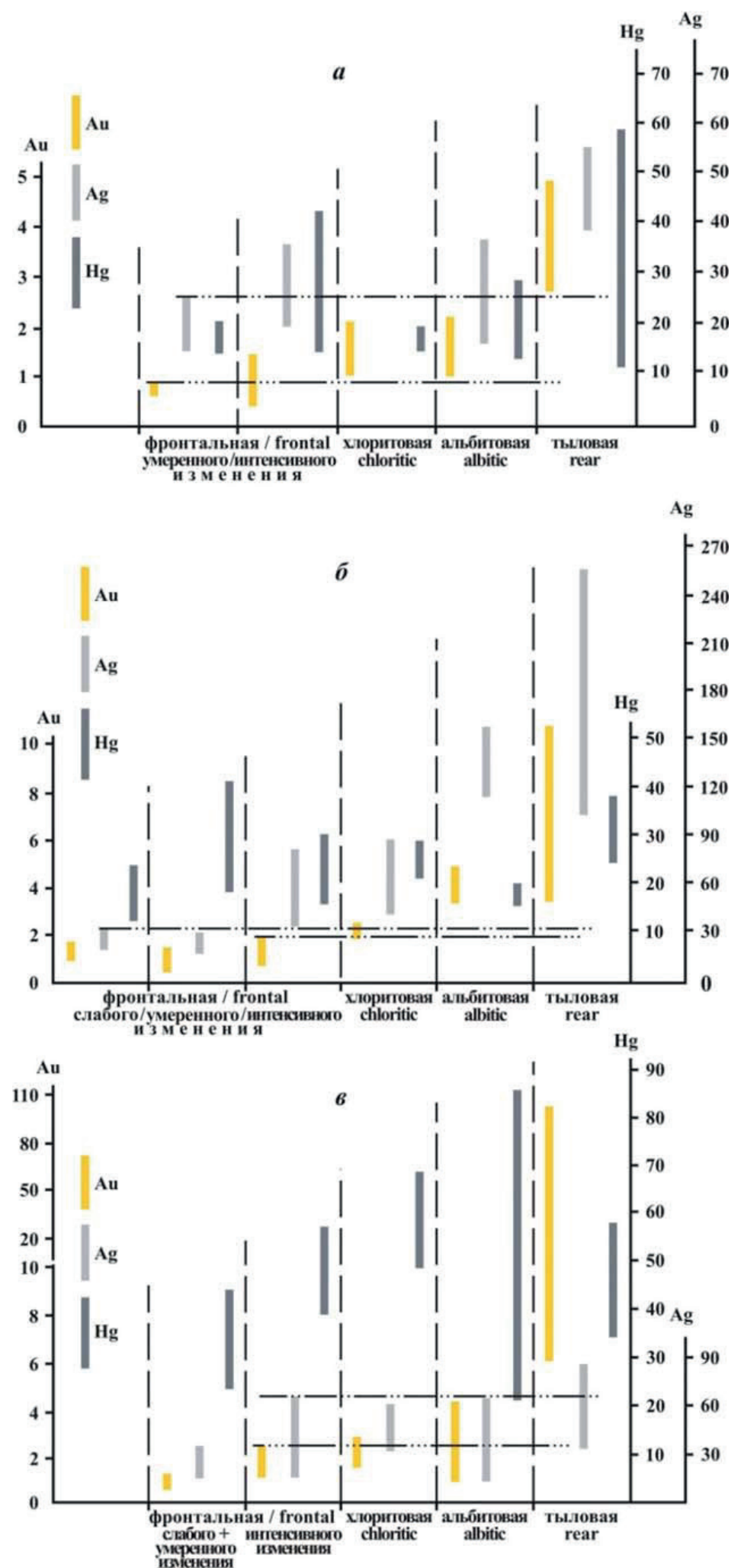

Рис. 2. Доверительные интервалы изленений среднего геолетрического содержания золота, серебра, ртути (мг/m) в линералого-петрохимических зонах околорудных метасолатических ореолов, образованных в квариевол диорите (а), углеродистых песчаноалевросланиах кедровской (б) Кедровского и углеродистых песчано-алевро-сланцах водораздельной (в) Каралонского месторождений толщ, (свит) (при 5 \% уровне значилости)

Fig. 2. Trust (ing) alteration intervals of average geometric content of gold, silver, mercury (mg/ $t$ ) in mineral-petrochemic zones of near-ore metasomatic haloes formed in quartz diorite (a), carbonaceous sandstone-aleuroslates of kedrovskaya (б), Kedrovskoe and in carbonaceous sandstone-aleuroslates of vodorazdelnaya ( 8 ) Karalonskoe deposits suites (attached to 5 per cent level of significance) 
Содержания металлов в метасоматитах обрамления рудных столбов, образованных в золоторудных кварцевых жилах и залежах жильно-прожилково-вкрапленных руд, особенно обогащенных сульфидами, всегда выше (табл. 1, колонки Ирокиндинского месторождения) сравнительно с участками рудных тел или рудными телами с рядовыми содержаниями (до 10 г/т) золота (табл. 1, колонки Кедровского, Каралонского месторождений). Основная масса золота и серебра осаждается в тыловых альбитовой и особенно березитовой зонах. В породах, в частности в черных сланцах позднерифейской мухтунной свиты в Ирокиндинском прогибе, не содержащих рудных тел, содержания металлов и в тыловых зонах метасоматических колонок остаются на субкларковых уровнях (табл. 1).

Таблица 2. Оценка параметров распределения рудогенных әлементов в минералого-петрохимических зонах рудовмешающего метасоматического ореола золоторудно 20 месторождения Сухой Лог (Западный участок)

Table 2. Appraisal of the parameters of oregenous elements distribution in mineral-petrochemic zones of mesothermal goldore Sukhoi Log deposit (Western section) orecontaining metasomatic halo

\begin{tabular}{|c|c|c|c|c|c|}
\hline \multirow{4}{*}{ 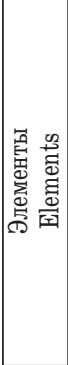 } & \multirow{4}{*}{$\begin{array}{c}\text { Параметры } \\
\text { распределения } \\
\text { Distribution } \\
\text { parameters }\end{array}$} & \multirow{2}{*}{\multicolumn{4}{|c|}{$\begin{array}{c}\text { Углеродистые филлиты, песчаники, } \\
\text { алевро-сланцы имняхской свиты }\left(\mathrm{R}_{3}\right) \\
\text { Carbonaceous phyllites, sandstones, } \\
\text { aleuro-slates imniahskaja suite }\left(\mathrm{R}_{3}\right) \\
\text { Минеральные зоны [число проб] } \\
\text { Mineral zones [number of samples] }\end{array}$}} \\
\hline & & & & & \\
\hline & & \multicolumn{2}{|c|}{\begin{tabular}{|l} 
Хлоритовая/Chloritic \\
\end{tabular}} & \multicolumn{2}{|c|}{ Альбитовая/Albitic } \\
\hline & & \begin{tabular}{|c|} 
Без суль- \\
фидов [19] \\
Without \\
sulphides
\end{tabular} & \begin{tabular}{|c|} 
С сульфи- \\
дами [6] \\
With \\
sulphides
\end{tabular} & $\begin{array}{c}\text { Без суль- } \\
\text { фидов [11] } \\
\text { Without } \\
\text { ulphides }\end{array}$ & $\begin{array}{l}\text { С сульфи- } \\
\text { дами [10] } \\
\text { With } \\
\text { sulphides }\end{array}$ \\
\hline \multirow{2}{*}{$\mathrm{Au}$} & $\overline{x_{2}}(\bar{x})$ & $3,4(3,5)$ & $10,1(10,3)$ & $3,9(5,0)$ & $20,9(35,3)$ \\
\hline & $t(s)$ & $1,4(1,3)$ & $1,2(2,4)$ & $2,0(4,3)$ & $2,7(49,0)$ \\
\hline \multirow{4}{*}{$\mathrm{Ag}$} & $\overline{\bar{x} z}(\overline{\bar{x}})$ & $26,9(28,3)$ & $40,3(45,7)$ & $29,1(33,5)$ & $63,2(65,6)$ \\
\hline & $t(s)$ & $1,4(8,9)$ & $1,7(23,8)$ & $1,8(19,8)$ & $1,3(20,2)$ \\
\hline & $r(\mathrm{Au}-\mathrm{Ag})$ & $-0,01$ & 0,5 & 0,2 & 0,4 \\
\hline & $\mathrm{Au} / \mathrm{Ag}$ & 0,13 & 0,25 & 0,13 & 0,33 \\
\hline
\end{tabular}

На западной периферии месторождения Сухой Лог карьером и скважинами вскрыты залежи жильно-прожилково-вкрапленных руд в промежуточных хлоритовой и смежной с тыловой альбитовой зонах крупнообъемной метасоматической колонки, образованной в черных сланцах имняхской и хомолхинской свит позднего рифея. Обычное в этом и подобных условиях неравномерное распределение в метасоматитах сульфидов - носителей значительной части золота и серебра - обеспечило дифференциацию проб на содержащие сульфиды, среди которых преобладает золотоносный пирит с редкой несущественной примесью галенита, сфалерита и других, и бессульфидные. Результаты анализов и их обработки (табл. 2) подтвердили общую закономерность - усиление интенсивности метасоматических преобразований пород сопровождается возрастанием содержаний того и другого металла при изменении количественных соотношений золота и серебра в пользу золота.
Таблииа 3. Оиенка параметров распределения рудогенных әлементов в минералого-петрохимических зонах рудовмещающего метасоматического ореола Вернинского золоторудного месторождения

Table 3. Appraisal of the parameters of oregenous elements distribution in mineral-petrochemic zones of mesothermal Verninskoe goldore deposit orecontaining metasomatic halo

\begin{tabular}{|c|c|c|c|c|c|}
\hline \multirow[b]{4}{*}{ 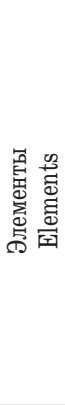 } & \multirow[b]{4}{*}{ 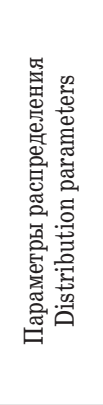 } & \multicolumn{4}{|c|}{ Минеральные зоны/Mineral zones } \\
\hline & & \multicolumn{2}{|c|}{ Альбитовая / Albitic } & \multicolumn{2}{|c|}{ Березитовая/Beresitic } \\
\hline & & \multicolumn{4}{|c|}{ Исходные горные породы / Initial rocks } \\
\hline & & 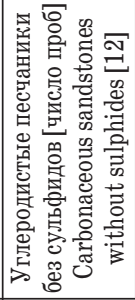 & 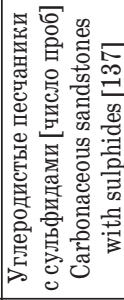 & 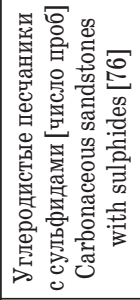 & 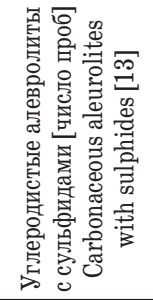 \\
\hline \multirow[t]{2}{*}{$\mathrm{Au}$} & $\overline{x 2}(\bar{x})$ & $2,3(2,4)$ & $13,0(23,6)$ & $39,2(309,0)$ & $37,0(55,0)$ \\
\hline & $t(s)$ & $1,3(0,55)$ & $2,5(47,1)$ & $4,8(1187)$ & $2,6(52,1)$ \\
\hline \multirow[t]{4}{*}{$\mathrm{Ag}$} & $\overline{x z}(\bar{x})$ & $33,5(38,3)$ & $52,3(65,4)$ & $78,6(125,0)$ & $143,7(187,5)$ \\
\hline & $t(s)$ & $1,7(20,6)$ & $1,8(67,0)$ & $2,2(198,0)$ & $2,2(145,0)$ \\
\hline & $r(\mathrm{Au}-\mathrm{Ag})$ & 0,22 & 0,44 & 0,61 & 0,81 \\
\hline & $\mathrm{Au} / \mathrm{Ag}$ & 0,07 & 0,25 & 0,50 & 0,26 \\
\hline \multirow[t]{4}{*}{$\mathrm{Hg}$} & $\overline{x z}(\bar{x})$ & $15,9(29,0)$ & Н/Д & $78,7(262,0)$ & Н/д \\
\hline & $t(s)$ & $5,1(25,1)$ & Н/д & $6,3(483,0)$ & Н/Д \\
\hline & $r(\mathrm{Au}-\mathrm{Hg})$ & 0,56 & $\mathrm{H} / \mathrm{A}$ & 0,30 & Н/д \\
\hline & $r(\mathrm{Ag}-\mathrm{Hg})$ & 0,90 & Н/Д & 0,63 & Н/д \\
\hline
\end{tabular}

В соседнем с Сухим Логом генетически однотипном с ним Вернинском месторождении, во вскрытом карьером и скважинами объеме которого залежи жильно-прожилково-вкрапленных руд образованы в альбитовой и тыловой березитовой зонах рудовмещающего метасоматического ореола, параметры распределения золота, серебра, ртути увеличены в тыловой зоне сравнительно со смежной альбитовой зоной ореола, образованного среди углеродистых песчаников и алевролитов аунакитской свиты позднего рифея (табл. 3). Как и в других месторождениях, в том числе в Сухом Логу, содержания металлов, включая ртуть, в бессульфидных черных сланцах и апосланцевых метасоматитах в удалении от рудных столбов и рудоконтролирующих (раствороподводящих) разломов в хлоритовой и нередко, как в данном случае, в альбитовой зонах не выходят за пределы субкларковых значений.

В месторождении Чертово Корыто, расположенном в Патомском нагорье в 150 км к северу от месторождения Сухой Лог, образованном в толще переслаивающихся углеродистых разнозернистых, тонко-мелкозернистых песчаников, алевролитов, аргиллитов раннепротерозойской михайловской свиты, пробы горных пород по техническим причинам не дифференцированы по содержанию сульфидов, участвующих в форме редкой тонкой вкрапленности. Крупная залежь жильно-прожилково-вкрапленных руд месторождения образована в объеме, сложенном метасоматитами углеродистой (хлоритовой с керогеном), хлоритовой (без керогена), альбитовой, тыловой березитовой зон, 
Таблица 4. Оценка паралетров распределения рудогенных элементов в минералого-петрохилических зонах рудовмещающего метасоматического ореола золоторудного месторождения Чертово Корыто

Table 4. Appraisal of the parameters of oregenous elements distribution in mineral-petrochemic zones of mesothermal goldore Chertovo Koryto deposit orecontaining metasomatic halo

\begin{tabular}{|c|c|c|c|c|c|c|c|}
\hline \multirow{3}{*}{ 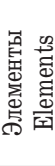 } & \multirow{3}{*}{$\begin{array}{c}\text { Параметры } \\
\text { распределения } \\
\text { Distribution } \\
\text { parameters }\end{array}$} & \multicolumn{6}{|c|}{ Исходные горные породы и минеральные зоны [число проб]/Initial rocks and mineral zones [number of samples] } \\
\hline & & \multicolumn{4}{|c|}{ Углеродистая/Carbonaceous } & \multirow[b]{2}{*}{$\begin{array}{l}\text { Хлоритовая } \\
\text { Chloritic } \\
\text { [39] }\end{array}$} & \multirow[b]{2}{*}{$\begin{array}{l}\text { Березитовая } \\
\text { Beresitic [18 }\end{array}$} \\
\hline & & $\begin{array}{c}\text { Разнозернистые песчаники } \\
\text { Different granular } \\
\text { sandstones [58] }\end{array}$ & \begin{tabular}{|c|} 
Tонко-мелко-зернистые \\
песчаники \\
Thin-finegranular sandstones [94]
\end{tabular} & $\begin{array}{c}\text { Алевролиты } \\
\text { Aleurolites [24] }\end{array}$ & $\begin{array}{c}\text { Аргиллиты } \\
\text { Argillites [23] }\end{array}$ & & \\
\hline \multirow{2}{*}{$\mathrm{Au}$} & $\overline{x_{2}}(\bar{x})$ & $7,3(60,7)$ & $7,7(37,5)$ & $5,6(22,8)$ & $5,1(12,4)$ & $16,0(82,7)$ & $22,1(93,5)$ \\
\hline & $t(s)$ & $4,9(231,1)$ & $4,5(105,1)$ & $4,2(59,3)$ & $3,4(23,6)$ & $5,1(210,2)$ & $5,6(163,1)$ \\
\hline \multirow{4}{*}{$\mathrm{Ag}$} & $\overline{x z}(\bar{x})$ & $77,9(104,4)$ & $78,5(89,7)$ & $72,0(81,5)$ & $87,8(152,9)$ & $81,0(122,0)$ & $84,9(115,1)$ \\
\hline & $t(s)$ & $1,9(145,4)$ & $1,7(52,4)$ & $1,7(39,0)$ & $2,6(244,6)$ & $2,1(193,1)$ & $2,1(122,3)$ \\
\hline & $r$ & 0,44 & 0,33 & $-0,05$ & $-0,03$ & 0,50 & 0,24 \\
\hline & $\mathrm{Au} / \mathrm{Ag}$ & 0,09 & 0,10 & 0,08 & 0,058 & 0,19 & 0,26 \\
\hline
\end{tabular}

многократно чередующихся в разрезе. Примесь 30лотоносных сульфидов сообщает породам повышенные против кларка содержания золота и серебра уже в углеродистой зоне, возрастающие, хотя и несущественно, в промежуточной хлоритовой и тыловой зонах рудовмещающей метасоматической колонки в сопровождении незначительно возрастающих стандартного множителя и стандартного отклонения содержания (табл. 4). Как обычно в березитовой зоне усиливается положительная корреляционная связь золота с серебром и возрастает золото-серебряное отношение.

Таблица 5. Оиенка параметров распределения рудогенных әлементов в гидротерлально излененных породах про межуточных и тыловых минералого-петрохимиче ских зон рудовмещающего метасоматического орео ла месторождения Чертово Корыто на различных гипсометрических уровнях

Table 5. Appraisal of the parameters of oregenous elements distribution in hydrothermal altered rocks of the Chertovo Ko ryto deposit orecontaining metasomatic halo intermediate and rear mineral-petrochemic zones on different hypsometric levels

\begin{tabular}{|c|c|c|c|c|}
\hline \multirow{2}{*}{ 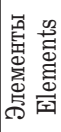 } & \multirow{2}{*}{$\begin{array}{c}\text { Параметры } \\
\text { распределения } \\
\text { Distribution pa- } \\
\text { rameters }\end{array}$} & \multicolumn{3}{|c|}{$\begin{array}{l}\text { Гипсометрические уровни [число проб] } \\
\text { Hypsometric levels [number of samples] }\end{array}$} \\
\hline & & $\begin{array}{c}\text { Подрудный } \\
\text { Underore [162] }\end{array}$ & $\begin{array}{l}\text { Рудный } \\
\text { Ore [440] }\end{array}$ & $\begin{array}{l}\text { Надрудный } \\
\text { Overore [289] }\end{array}$ \\
\hline \multirow{2}{*}{$\mathrm{Au}$} & $\overline{x z}(\bar{x})$ & $50,0(208,8)$ & $759,2(1505,3)$ & $11,0(159,1)$ \\
\hline & $t(s)$ & $9,4(390,6)$ & $5,4(3655,2)$ & $13,3(661,9)$ \\
\hline \multirow{3}{*}{$\mathrm{Ag}$} & $\overline{\bar{x} 2}(\bar{x})$ & $130,5(187,2)$ & $175,1(277,4)$ & $119,7(245,5)$ \\
\hline & $t(s)$ & $2,0(267,2)$ & $2,3(475,2)$ & $1,8(1763,4)$ \\
\hline & $\mathrm{Au} / \mathrm{Ag}$ & 0,38 & 4,00 & 0,08 \\
\hline \multirow{3}{*}{ As } & $\overline{x z}(\bar{x})$ & $80(602)$ & $436(1447)$ & 40(118) \\
\hline & $t(s)$ & $5,0(1817)$ & $5,2(2470)$ & $3,0(516)$ \\
\hline & $\mathrm{Au} / \mathrm{As}$ & 0,0006 & 0,0018 & 0,00025 \\
\hline
\end{tabular}

Объемная геохимическая зональность месторождения, выраженная в закономерном изменении параметров распределения металлов в промежуточных и тыловых минералого-петрохимических зонах рудовмещающего метасоматического ореола, сочетается с объемной геохимической зональностью, выраженной в закономерном изменении параметров распределения рудогенных золота, серебра, мышьяка - геохимического спутника золота на подрудном, рудном, надрудном гипсометрических уровнях (табл. 5). В частности, сравни- тельно с объемными подрудным и надрудным уровнями объемный рудный уровень выделяется более чем на порядок высоким содержанием в метасоматитах золота, более высоким содержанием серебра и мышьяка, на порядок более высоким золото-серебряным отношением, повышенным золото-мышьяковым отношением. Перечисленными параметрами распределения в метасоматитах металлов, которые согласуются с таковыми тыловых минералого-петрохимических зон рудовмещающих метасоматических ореолов, оконтуривается рудная залежь месторождения.

\section{Обсуждение и выводы}

Доказанное предшественниками-профессионалами [1-4] участие в составе околорудных (рудовмещающих) метасоматических ореолов в месторождении Сухой Лог и других золоторудных месторождениях «черносланцевого типа» Ленского района метасоматитов сопряженных березитовой и пропилитовой формаций служит одним из важнейших, наряду с другими, доказательств вещественно-генетической однородности оруденения, образованного в черносланцевом и кристаллическом субстрате. Поскольку образование березитов не было предусмотрено предложенной в середине прошлого столетия метаморфогенно-гидротермальной гипотезой, но разработчикам гипотезы надо было поддерживать ее как отличную от других гипотез "на плаву», то есть в конкурентоспособном состоянии, возникла потребность искать основания для опровержения факта образования березитов в черных сланцах в процессах околорудного метасоматизма и ограничиться пропилитами, «трансформировав» их в производные регионального метаморфизма гидратации фации зеленых сланцев. Атаки на березиты не замедлили себя ждать.

Первая попытка опровержения выводов предшественников о березитовом (березит-лиственитовом) профиле околорудных метасоматитов Сухого Лога и Ленского золотоносного района предпринята авторами идеи метаморфогенно-гидротермального рудообразования [5, 6], в том числе [6] на основе петрохимических пересчетов 482 химических силикатных анализов проб, объединенных в 
выборки по нескольку десятков проб в каждой с учетом гипсометрического уровня опробования, литологического состава исходных пород (песчаники, алевролиты), расстояния отбора проб от жил и рудных зон.

Указание на учет принадлежности проб к субфациям регионального метаморфизма гидратации (биотит-хлоритовой, хлорит-серицитовой) сочетается с дифференциацией проб по степени изменений пород на «исходные», «слабо измененные», «интенсивно измененные» без описания их минеральных составов, минеральных преобразований, количественных оценок интенсивности изменений, и поэтому выборки представляются сформированными некорректно. Методически некорректно также рассчитывать баланс петрогенных и рудных компонентов, то есть искать внешние или внутренние (местные породные на уровнях опробования) источники вещества для жил и жильных зон, определяя средний химический состав каждой пробы, «...исходя из среднего состава и степени распространенности (представительности) в с е х слагающих ее образований, в том числе кварцевых жил и в различной степени измененных пород” (разрядка наша, - И.К.) [6, с. 137]. Невозможно, скажем, судить о выносе кремнезема из измененной породы и об образовании за счет вынесенного кремнезема кварцевой жилы - обычного явления в процессе березитизации, смешивая, как это выполнял и рекомендовал В.А. Буряк, материал этой породы и кварцевой жилы в одну пробу - вынос кремнезема из измененной породы не будет зафиксирован. Поэтому вывод В.А. Буряка, согласно которому «...широко распространенные ранее представления ... о том, что рассматриваемые процессы по химизму характеризуются исключительным постоянством, проявляются в постоянном привносе калия и углекислоты и выносе кремнезема и натрия при относительной стабильности содержания других элементов, очевидно, не могут быть приняты» [6, с. 143], не очевиден, напротив, ведет к запутыванию вопроса, так как на такого рода некорректных выводах основано противопоставление В.А. Буряком (и не только) минералого-петрохимической сущности околорудных изменений черных сланцев, с одной стороны, и разнообразных пород в магматогенно-гидротермальных месторождениях, с другой.

B.А. Русинов с соавторами, позднее диагностировавшие в Сухом Логу минеральный состав участвующего в околорудном метасоматическом ореоле месторождения метасоматита, отрицают факт участия березита, ссылаясь на отсутствие в околорудной метасоматической колонке еще более тыловой, чем березитовая, кварц-серицитовой зоны [7]. Последняя существует в модели, следующей из теории метасоматической зональности Д.С. Коржинского, но в природных околорудных (рудовмещающих) метасоматических ореолах рудных месторождений образованию тыловой двухминеральной кварц-серицитовой зоны препятствует не уч- тенная в теории встречная, из трещинных растворов в поровые, диффузия компонентов, формирующая полиминеральный состав в том числе тыловой, а не только промежуточной, согласно теории, зоны [8], в данном случае отвечающий полиминеральному березиту.

Как известно и следует из приведенных материалов, зональная структура околорудных метасоматических ореолов месторождения Сухой Лог и других обсуждаемых месторождений «черносланцевого типа» по минералого-петрохимическому содержанию не составляет исключения из зональной структуры типовой минералого-петрохимической зональности околорудных метасоматических ореолов мезотермальных месторождений золота, урана, цветных металлов, образованных и в кристаллическом субстрате [8, 9], отвечающих в том и другом субстрате сочетанию березитовой в тыловых и пропилитовой в периферийных зонах формаций. Апочерносланцевые метасоматиты месторождения в обрамлении рудоконтролирующего раствороподводящего глубинного Кадали-Сухоложского разлома обогащены углекислотой, восстановленной серой, калием, фемофильными элементами в ассоциации - магнием, железом, титаном, фосфором, зафиксированными в обильных магнезиально-железистых карбонатах, лейкоксене, рутиле, апатите, а также обогащены [10], в опровержение утверждения об отсутствии в месторождении околорудных геохимических ореолов [11], золотом, серебром, платиной, палладием, никелем, кобальтом, хромом, цинком, свинцом, медью, редкими землями, вольфрамом, молибденом, цирконием. Каждый из этих металлов образует собственные многочисленные минеральные фазы.

На основе изотопных отношений углерода, серы, редкоземельных радиогенных элементов реконструированы два источника металлов и доставивших их в образующееся месторождение флюидов, один из которых глубинный [12]. По заключениям Н.П. Лаверова с коллегами, в область рудоотложения поступили с металлоносными флюидами $\mathrm{CO}_{2}$, золото, платина, вольфрам, молибден, редкие земли, никель, кобальт, хром, свинец, цинк, В.В. Дистлера с коллегами [13] - в составе руд участвуют самородные железо, олово, свинец, титан, монацит.

Доказанная в месторождениях «сухоложского» типа прямая корреляционная связь между содержаниями золота и металлов платиновой группы [14], участие в околорудных (рудовмещающих) метасоматических и геохимических ореолах и рудах никелистого хлорита [15], ртути [16-18], подчиняющейся (рис. 1,2 ) околорудной метасоматической зональности, - факты, которые служат дополнительными индикаторами генетической связи золотого оруденения с базитовым магматизмом.

После всего, что выполнили предшественники в исследовании обсуждаемой проблемы, утверждение отсутствия в Сухом Логу и, очевидно, в других месторождениях «сухоложского типа» околоруд- 
ных метасоматических и геохимических ореолов [11] не отвечает реальной ситуации, но согласуется с новой эксгаляционно-осадочной версией образования этих месторождений и, вероятно, продиктовано необходимостью защищать эту версию.

Если природа создала месторождения по эксгаляционно-осадочному сценарию, но мало похожие на ножки «грибов» пологие залежи жильно-прожилково-вкрапленных руд с секущими стратификацию вмещающих толщ черных сланцев контурами [11] представляют, согласно версии, верхнюю осадочную стратиформную составляющую свойственных месторождениям типа куроко грибообразных рудных тел («шляпки») без гидротермально-метасоматических «ножек», околорудных метасоматических березитовой формации и геохимических ореолов - непременных спутников гидротермально-метасоматических руд не должно быть. Поскольку те и другие ореолы существуют, остается предположить, что более чем четырехкилометровая по пологому падению Главная рудная залежь Сухого Лога и другие подобные менее объемные залежи этого месторождения, следующие рудоконтролирующему (раствороподводящему) Кадали-Сухоложскому глубинному разлому, образованы как гидротермально-метасоматические в породах придонной области конседиментационного прогиба под термодинамическим и физико-химическим барьером, созданным в придонной области толщей океанских (морских) вод и грунтовыми водами ниже дна. В таком случае весь ансамбль накопленных в Ленском районе фактов следует соотнести с этим выводом. В любом случае факты нельзя отменять или о них «забывать», а надо их использовать в обоснование или опровержение предложенных версий.

Выводу о гидротермально-метасоматическом происхождении рудных залежей Сухого Лога противоречит факт образования в них слойчатой текстуры породы (руды?), в которой слойки (не эпигенетические полоски?, - И.К.) сульфидов чередуются со слойками силикатов черных сланцев и которая призвана [11] служить признаком осадочного их (залежей) происхождения. Поскольку, согласно сформулированному предположению, рудные залежи могли быть образованы только в породах ниже дна водоема, но в непосредственной от него близости, можно допустить достижение холодных придонных вод отдельными струями общего потока поднимающихся горячих металлоносных растворов, смешение последних с придонными водами, нарушение химического равновесия в смеси и, как следствие, осаждение на дно растворенного вещества в верхних частях образующихся гидротермально-метасоматических залежей на локальных участках функционирования «черных курильщиков» .

Если этот сценарий с учетом обычного явления в осадочном процессе - колебательных движений (воздымание, погружение) дна водоемов - реализован природой, представление о гидротермально- метасоматическом происхождении рудных залежей с фрагментами осадочной составляющей нет оснований отменять.

В свою очередь, популярному представлению о метаморфогенно-гидротермальном происхождении оруденения в черных сланцах [19-37] Ленского района противоречат данные, раскрывающие последовательность геологических событий посредством радиологических определений их возраста. Н.П. Лаверов с соавторами свидетельствуют $[12,38]:$ рудовмещающие толщи черных сланцев образованы около 1000 млн л. назад, их региональный метаморфизм нагревания происходил $510 \pm 30$ млн л. назад, возраст метасоматических рудных залежей составляет 440 млн л., золотоносных кварцевых жил $-315 \pm 15$ млн л. Приходится предположить возраст залежей завышенным, так как он определен по валовым пробам, содержащим древний мусковит и биотит этапа регионального метаморфизма нагревания мусковит-биотитовой ассоциации фации зеленых сланцев, и более молодой мусковит-серицит этапа околорудного (околожильного) метасоматизма с их $\mathrm{Rb}-\mathrm{Sr}$ системами. Один мусковит от другого не отделим. Скорее всего, возраст рудных залежей и продуктивных жил близок - они образованы в одном с выносом из пород образующего кварцевые жилы кремнезема процессе, хотя в монофракции околожильного мусковита-серицита также нельзя исключать участие древнего и молодого минерала, но без биотита, который в околожильном березите полностью замещен мусковитом-серицитом. Значительный возрастной перерыв между этапами регионального метаморфизма и рудообразования, следующий из этих данных, исключает участие ранних метаморфических процессов в создании более поздних месторождений золота.

В последовательности геологических событий, непосредственно предшествовавших образованию мезотермальных генетически однородных месторождений золота в кристаллическом субстрате и толщах черных сланцев и сопровождавших его [39-43], природа оставляет следы, раскрывающие, в частности, пространственно-временные и причинно-следственные соотношения рудообразования с магматизмом.

В Ленском районе следы материализованы в составе антидромного гранит-диорит-долеритового флюидно-рудно-магматического комплекса, включающего не вскрытый эрозией массив гранитоидов под месторождением Сухой Лог, связанный с ним, но выходящий на дневную поверхность гранитный Константиновский шток, сопровождающие массив многочисленные дорудные дайки средне-кислых пород аглан-янского комплекса, поздние ассоциации чередующихся по времени образования с рудно-минеральными комплексами базитовых даек кадали-бутуинского комплекса. K-Ar возраст биотита гранитоидов штока составляет $300 \pm 20$ млн л., $\mathrm{Sm}-\mathrm{Nd}$ возраст (по валовым пробам) базитовых даек $-312 \pm 59$ млн л. [44]. 
В числе базитовых даек С.Д. Шером описаны дожильные и послежильные [45].

Дожильные дайки содержат многочисленные кварцевые прожилки, гидротермально изменены. Реликтовые порфировые вкрапленники плагиоклаза, оливина, пироксена частично замещены псевдоморфными агрегатами альбита, хлорита, магнезиально-железистых карбонатов; цемент сложен теми же минералами с примесью кварца и пирита. Пирит и магнезиально-железистые карбонаты по размерам кристаллов-ромбоэдров, составу, содержанию элементов-примесей (серебра, цинка, свинца, висмута и других) аутентичны этим же минералам, образованным в составе апочерносланцевых околорудных березитов.

Послежильные дайки не содержат кварцевых прожилков, в контактах с кварцем сопровождаются зонами закалки. Сложены реликтовыми магматическими минералами - плагиклазом-лабрадором (до 15 об. \%), авгитом (до 30 об. \%), магнетитом, гранатом, новообразованными минералами в ассоциации зеленовато-бурого, грязно-зеленого биотита (до 40 об. \%), обыкновенной роговой обманки (до 10 об. \%), цоизита, апатита, магнетита, пирита, хлорита, серицита, кальцита, магнезиально-железистых карбонатов. Биотит и другие перечисленные минералы частично замещают роговую обманку, лабрадор, авгит. Описанные дайки, первоначально диагностированные С.Д. Шером [45] как лампрофиры, впоследствии переквалифицированы в диабазы (долериты) [46], подвергшиеся метасоматическим преобразованиям с обогащением аподолеритовых метасоматитов калием в биотите (до 5,36 мас. \%), углекислотой $\left(\mathrm{CO}_{2}\right)$ в карбонатах (до 1,06 мас. \%), магнием ( $\mathrm{MgO}$ ) (до 16,65 мас. \%) и снижением содержания натрия $\left(\mathrm{Na}_{2} \mathrm{O}\right)$ (до 0,07 мас. \%) и кремнезема. С усилением степени гидротермальных изменений даек в аподайковых метасоматитах возрастает содержание золота - от 1,3 мг/т (21 проба) в слабо измененных до 11 мг/т (22 пробы) в интенсивно измененных.

Ранняя, этапа метасоматизма, ассоциация высокотемпературных биотита и обыкновенной роговой обманки базитовых (послежильных по С.Д. Шеру) даек, преобразованных в метасоматиты среди не измененных гранитов, черных сланцев и других пород, пересекающих ранние рудно-минеральные комплексы и пересекаемых поздними, выполняющих в числе базитовых даек других (дорудных, послерудных) генераций оперяющие рудоконтролирующий Кадали-Сухоложский глубинный разлом структуры [47], служит в согласии с известным физическим явлением $[48,49]$ индикатором аккумулирующей в горячем состоянии среди холодных пород горячие металлоносные растворы и флюидопроводящей функции внутрирудных даек долеритов. Вместе с тем фиксируемый во внутрирудных дайках-флюидопроводниках долеритов калиево-сернисто-углекислотный профиль метасоматизма [9] унаследован процессом околорудного метасоматизма, но с образованием в берези- тах, в отличие от аподолеритовых метасоматитов, относительно низкотемпературного серицита, а не биотита, вследствие дальнейшего при фильтрации охлаждения растворов и при отсутствии, вероятно, по этой же причине, в средне-низкотемпературных березитах метасоматической обыкновенной роговой обманки. В сочетании с фемофильной $(\mathrm{Mg}, \mathrm{Fe}, \mathrm{Ti}, \mathrm{P})$ специализацией внутридайковых биотит-роговообманковых и околорудных в обрамлении глубинных разломов метасоматитов (березитов) $[8,9]$ эти факты квалифицируют внутрирудные дайки-флюидопроводники долеритов как связующее звено между базитовыми очагами мантии - источниками базитовых расплавов и золотоносных растворов и образованными этими растворами на верхних горизонтах земной коры мезотермальными месторождениями золота.

Приведенные данные дополняют изотопные отношения участвующих в составе руд элементов. Обращается внимание на аномальное облегчение серы сульфидов в рудных залежах Сухого Лога, обусловленное привносом металлоносными растворами изотопно легкой мантийной серы [13]. Участие в образовании руд месторождения Сухой Лог флюидов и металлов, генерированных в мантии, доказывается также расширенными интервалами значений изотопных отношений восстановленных и окисленных форм углерода $\left({ }^{13} \delta \mathrm{C}=-30 \ldots 3,5 \%\right.$, ${ }^{18} \delta 0=16,3 \ldots 30,2 \%$ ), серы и радиогенных изотопов TR [10], отвечающими мантии изотопными отношениями углерода карбонатов-порфиробластов руд [50]. Согласно одной из последних версий рудообразования [11], наиболее мощные и наиболее золотоносные залежи жильно-прожилково-вкрапленных руд в месторождениях «сухоложского типа», образованные на конседиментационном, метаморфизованные на коллизионном этапах в областях раствороподводящих каналов вблизи единых центров повышенной эндогенной активности разломов фундамента и узлов их пересечения, содержат сульфиды с высокой изотопной гомогенностью серы ( ${ }^{34} \delta \mathrm{S}= \pm 3 \%$ ), отвечающей метеоритному стандарту.

Извлеченные из месторождения Сухой Лог, месторождений Ленского и других [41] золоторудных районов, образующие согласованный ансамбль, взаимно дополняющие один другой факты составляют основу двух геолого-генетических сценариев, следуя которым природа создает в черносланцевом и кристаллическом субстрате золотосодержащие колчеданные и золоторудные месторождения.

Оба сценария активированы одним явлениемпроцессом - внедрением в мантию и земную кору по зонам сверхглубинной проницаемости, вероятно, из жидкого ядра планеты высокотемпературных газовых флюидов-теплоносителей, плавящих на своем пути мантию и земную кору - создающих «горячие точки». В мантии и коре возникают сосуществующие бассейны - очаги соответственно базитового и гранитного составов с последующим ох- 
лаждением и кристаллизацией в опережающем по меркам геологического времени режиме коровых гранитных расплавов в относительно холодном сравнительно с мантией коровом субстрате.

Накапливающиеся в процессе кристаллизации в нижних частях магматических камер остаточные гранитные расплавы в случае их геохимической (металлогенической) специализации на литофильные, сидерофильные (Be, $\mathrm{Li}, \mathrm{Ta}, \mathrm{Nb}, \mathrm{Rb}, \mathrm{Cs}$, $\mathrm{Sn}$ и др.) металлы в разных сочетаниях в благоприятных термодинамических и физико-химических условиях способны создавать редкометальные пегматиты, генерировать металлоносные растворы, образующие редкометальные месторождения. В результате кристаллизации гранитных расплавов образуются массивы, плутоны, батолиты палингенных гранитоидов - ранние составляющие антидромных флюидно-рудно-магматических комплексов.

Мантийные базитовые очаги продолжают функционировать, доказательством чему служат дайки долеритов, умеренно-щелочных долеритов, лейкодолеритов с нормативными для них минералого-химическими составами [9, 39-43], локализованные, в том числе, среди гранитоидов. В свою очередь, отсутствие в золоторудных месторождениях дорудных минглинг-даек - «гибридных» даек - факты, которые служат доказательством кристаллизации гранитных расплавов во всем объеме магматической камеры, включая остаточные расплавы в ее низах, до инъекции ранней порции базитовых расплавов и следующей за ней ранней порции золотоносных растворов. Очевидно, вследствие этого смешение поднимающихся из мантийных очагов базитовых расплавов с гранитными исключено, а золотоносные растворы не могут быть генерированы в уже не существующих остаточных гранитных расплавах. Они могут быть генерированы в продолжающих функционировать эманационно активных базитовых очагах мантии. Генерация золотоносных растворов и аккумуляция их наряду с разломами еще горячими внутрирудными базитовыми дайками-флюидопроводниками через промежуток времени, в течение которого дайки не успевают остыть, сочетаются с наследующей фемическую специализацию базитовых расплавов фемической специализацией золотоносных растворов и мантийными соотношениями изотопов углерода карбонатов и серы сульфидов руд и околорудных (рудовмещающих) метасоматитов.

Описанный сценарий процесса генерации золотоносных растворов без участия метаморфизма сменяется двумя возможными геолого-генетическими сценариями образования без участия метаморфизма месторождений золота.

Первый предполагает инъекцию золотоносных растворов в земную кору океанического типа - в приконтинентальных областях океанов - зонах Беньофа, в срединно-океанических хребтах, в структурах типа Восточно-Тихоокеанского поднятия, в рифтах - Красноморском фрагменте Восточ-
но-Африканского рифта, в трансформных разломах. Здесь образуются гидротермально-осадочные типа «куроко» месторождения, сочетающие в себе рудные тела грибообразной формы, - сложенные, как правило, колчеданами осадочные залежи «шляпы» и гидротермально-метасоматическими прожилково-вкрапленными рудами «ножки грибов» в раствороподводящих разломах дна водоемов. В случаях активных донных течений стратиформные называемые вулканогенно-осадочными рудные залежи пространственно разобщены с субвертикальными гидротермально-метасоматическими телами, образованными в раствороподводящих разломах дна. Естественно, стратиформные залежи осадочных руд, в отличие от Сухого Лога, не должны содержать признаки околорудного метасоматизма при том, что распределение сопровождающих руды элементов определяется гидродинамическими режимами придонных вод, но не может подчиняться минералого-петрохимической зональности не существующих околорудных метасоматических ореолов.

Согласно второму сценарию, предполагающему инъекцию золотоносных растворов в земную кору континентального типа, на рубежах встречи холодных грунтовых вод - термодинамических и физико-химических барьерах с поднимающимися горячими золотоносными растворами - образуются гидротермально-метасоматические и/или кварцево-жильные мезотермальные руды золота в сопровождении околорудных (рудовмещающих) метасоматических ореолов - зональных колонок, в том числе пропилит-березитового минералого-петрохимического профиля, и геохимических ореолов, структура которых подчиняется околорудной минералого-петрохимической зональности, как это фиксируется в месторождении Сухой Лог и множестве мезотермальных месторождений золота, образованных в кристаллическом и черносланцевом субстрате (табл. 1-4) [41].

Вероятно существование термодинамических и физико-химических барьеров и в верхних горизонтах океанической коры вследствие проникновения океанических (морских) вод на некоторую глубину в породы дна. В случае подъема здесь горячих металлоносных растворов возможно отложение рудной минерализации на барьерах, то есть под дном, и образование не осадочных залежей, а пологих вдоль барьеров, гидротермально-метасоматических залежей прожилково-вкрапленных руд, подобных Главной и другим залежам Сухого Лога.

\section{Заключение}

Как отмечалось $[8,9]$, в ученом сообществе, занятом проблемами рудной геологии, существуют обусловленные субъективными причинами - человеческим фактором - негативные явления, продуцирующие не живительную для развития науки дискуссию, а суррогат ее, искусственно навязываемый посредством вброса в научный оборот недостоверных «фактов» или исключения из учета, 
анализа, обсуждения, обобщения опубликованных в не самых непопулярных изданиях вполне достоверных фактов, очевидно, по причинам, далеким от поисков истины. Наиболее популярные негативные явления заключаются в следующем.

- Вброс в научный оборот статистически не выверенного «факта» о приуроченности гидротермальных месторождений золота к породам, обогащенным металлом, инициировал более полувека назад, несмотря на предшествующий опыт отказа от литораль-секреционной гипотезы, возникновение метаморфогенно-гидротермальной гипотезы, популярной в разных версиях до сих пор при том, что этот «факт» был вскоре повторно опровергнут по причине признания, в том числе автором вброса В.А. Буряком, одинаково низких (2...4 мг/т) содержаний золота в черных сланцах золотоносных и не золотоносных районов.

- Отрицание с методически ущербными попытками обоснования одновременно с презентацией метаморфогенно-гидротермальной гипотезы участия описанных С.Д. Шером [1] метасоматитов березитовой формации в составе околорудно измененных пород (черных сланцев) Ленского района.

- Отрицание без обоснования в новейшее время в Сухом Логу и месторождениях золота «сухоложского типа» околорудных метасоматических и геохимических ореолов, описанных предшественниками-профессионалами [2-4, 7, $10,12,51]$, породившее новую для Ленского района эксгаляционно-осадочную гипотезу рудообразования и как бы способствующее поддержанию ее в конкурентоспособном состоянии, но не отвечающее реальной ситуации.

- Исключение апологетами метаморфогенно-гидротермальной и гранитогенной гипотез из учета, анализа, обсуждения, обобщения ассоциации фемофильных элементов в составе $\mathrm{Mg}, \mathrm{Fe}$, $\mathrm{Ti}, \mathrm{P}$, образующих в околорудных метасоматических ореолах мезотермальных месторожде-

\section{СПИСОК ЛИТЕРАТУРЫ}

1. Шер С.Д. Околорудные изменения, сопутствующие золотокварцевым жилам в Ленском золотоносном районе // Метасоматические изменения боковых пород и их роль в рудообразовании. - М.: Недра, 1966. - С. 282-291.

2. Коновалов И.В. Околорудная зональность одного золоторудного месторождения (Ленский район) // Геология и геофизика. 1973. - № 1. - C. 123-125.

3. Шмотов А.П. Тектонические деформации и сопряженные с ними гидротермально-метасоматические преобразования вмещающих пород (Ленский золотоносный район) // Доклады АН CCCP. - 1974. - T. 218. - № 1. - С. 178-181.

4. Шаров В.Н., Шмотов А.П., Коновалов И.В. Метасоматическая зональность и связь с ней оруденения. - Новосибирск: Наука, 1978. $-103 \mathrm{c}$

5. Буряк В.А., Летников Ф.А. 0 роли процессов регионального метаморфизма и ультраметаморфизма в развитии золотого оруденения // Вопросы геологии месторождений золота. Томск: Изд-во Томского университета, 1970. - С. 19-24. ний золота, в том числе апочерносланцевых, в том числе в Сухом Логу, контрастные аномалии, наследующие фемофильную специализацию аподолеритовых метасоматитов, образованных золотоносными растворами во внутрирудных дайках-флюидопроводниках долеритов.

- Исключение апологетами обеих гипотез из учета, анализа, обсуждения, обобщения базитовых даек, образованных в мезотермальных месторождениях одновременно с рудами посредством чередования во времени инъекций базитовых расплавов и золотоносных растворов, даек-флюидопроводников, которые в сочетании с минералого-петрохимическим и геохимическим содержанием внутридайковых метасоматитов, изотопными отношениями углерода карбонатов и серы сульфидов руд и околорудных метасоматитов служат индикаторами генерации металлоносных растворов в базитовых очагах мантии, в сочетании с контролем базитовых даек и мезотермальных месторождений золота глубинными разломами - связующим звеном между базитовыми очагами мантии и месторождениями в верхних горизонтах земной коры.

Возврат, включение в научный оборот всех накопленных достоверных, проверяемых, повторяющихся во множестве мезотермальных месторождений золота, образованных в разнообразном кристаллическом и черносланцевом субстрате, фактов, как это следует из приведенных материалов, обеспечивает обоснование представления о геолого-генетической однородности месторождений той и другой совокупности как магматогенно-гидротермальных и концепции, наиболее приближенной $\kappa$ написанному и реализованному природой сценарию, содержание которого доказывается результатами реконструкции рудообразующих процессов на основе изучения всех оставленных ими, в том числе неудобных для многих, вещественных следов.

6. Буряк В.А. Метаморфизм и рудообразование. - М.: Недра, 1982. $-256 \mathrm{c}$.

7. Русинов В.Л., Русинова 0.В., Кряжев С.Г. Околорудный метасоматизм терригенных углеродистых пород в Ленском золоторудном районе // Геология рудных месторождений. - 2008. T. 50. - № 1. - C. 3-46.

8. Кучеренко И.В. Проблемы рудной геологии и человеческий фактор. Часть 1. Минералого-петрохимическая зональность околожильных метасоматических ореолов в мезотермальных месторождениях золота: теория, эксперимент, природа // Известия Томского политехнического университета. Инжиниринг георесурсов. - 2017. - Т. 328. - № 7. - С. 105-118.

9. Кучеренко И.В. Проблемы рудной геологии и человеческий фактор. Часть 2. Магматизм и мезотермальное рудообразование // Известия Томского политехнического университета. Инжиниринг георесурсов. - 2018. - Т. 329. - № 6. C. $148-170$.

10. Рудообразующая система золото-платинового месторождения Сухой Лог / Н.П. Лаверов, В.В. Дистлер, Ю.Г. Сафонов, 
И.В. Чернышов, М.А. Юдовская, Г.Л. Митрофанов, В.К. Немеров // Металлогения, нефтегазоносность и геодинамика Северо-Азиатского кратона и орогенных поясов его обрамления: Материалы II Всероссийского металлогенического совещания. - Иркутск, 25-28 августа 1998 г. - Иркутск: 000 «Сантай», 1998. - С. 296.

11. Кряжев С.Г. Генетические модели и критерии прогноза золоторудных месторождений в углеродисто-терригенных комплексах: автореф. дис. ... д-ра геол.-минер. наук. - М., 2017. - 52 с.

12. Новые данные об условиях рудоотложения и составе рудообразующих флюидов золото-платинового месторождения Сухой Лог / Н.П. Лаверов, В.Ю. Прокофьев, В.В. Дистлер, М.А. Юдовская, А.М. Спиридонов, В.И. Гребенщикова, Н.Л. Матель // Доклады РАН. - 2000. - Т. 371. - № 1. C. $88-92$.

13. Формы нахождения металлов платиновой группы и их генезис в золоторудном месторождении Сухой Лог (Россия) / В.В. Дистлер, Г.Л. Митрофанов, В.К. Немеров, В.А. Коваленкер, А.В. Мохов, Л.К. Семейкина, М.А. Юдовская / Геология рудных месторождений. - 1996. - Т. 38. - № 6. - С. 467-484.

14. Маракушев А.А., Русинов В.Л. Природа золотоносности углеродистых толщ // Доклады РАН. - 2005. - Т. 401. - № 4. C. $515-520$.

15. Состав метасоматических минералов золоторудного месторождения Сухой Лог как критерий его генетической связи с базитгипербазитовым магматизмом / В.Л. Русинов, О.В. Русинова, С.Е. Борисовский, Е.И. Алышева // Доклады РАН. - 2005. T. 405. - № 5. - C. 661-665.

16. Озерова Н.А. Ртуть и эндогенное рудообразование. - М.: Наука, 1986. - 155 с.

17. Степанов В.А., Моисеенко В.Г. Геология золота, серебра и ртути. Владивосток: Дальнаука, 1993. - 228 с.

18. Уникальная ассоциация природной амальгамы золота, киновари, самородных металлов и карбидов Фадеевского руднорассыпного узла, Приморье / В.П. Молчанов, А.И. Ханчук, Е.И. Медведев, Л.П. Плюснина // Доклады РАН. - 2008. T. 422 . - № 4. - C. 536-538.

19. Evidence of local sourcing of sulphur and gold in an Archaean sediment-hosted gold deposit / Vikraman Selvaraja, M.L. Fiorentini, Heejin Jeon, D.D. Savard, C.K. Laflamme, P. Guagliardo, S. Caruso, Thi-Hao Bui // Ore Geology Reviews. - 2017. V. 89. - P. 909-930.

20. Multiple mineralization events in the Zhaxikand $\mathrm{Sb}-\mathrm{Pb}-\mathrm{Zn}-\mathrm{Ag}$ deposit and their relationship with the geodynamic evolution in the North Himalayan Metallogenic Belt, South Tibet / D. Wang, Y. Sheng, R. Mathur, J. Jiang, S. Shang, J. Sheng, M. Yu // Ore geology Reviews. - 2019. - V. 105. - P. 201-215.

21. Khanchuk A.I., Plyusnina L.P., Nikitenko E.M. The Noble Metals Distribution in the black shales of the Degdekan Gold deposit in Northeast Russia // Russian journal of Pacific Geology. 2011. - V. 5. - № 2. - P. 89-96.

22. Vasilyeva I.E., Shabanova E.V., Razvozzaeva E.A. Noble metals in the insoluble carbonaceous substance of black shales and ores: Direct atomic emission data // Geochemistry International. 2012. - V. 50. - № 9. - P. 771-776.

23. Relationship between metamorphism and ore formation at the Sukhoi Log gold deposit hosted in black slates from the data of $\mathrm{U}-\mathrm{Th}-\mathrm{Pb}$ isotopic SHRIMP-dating of accessory minerals M.A. Yudovskaya, V.V. Distler, N.V. Rodionov, A.V. Mokhov, A.V. Antonov, S.A. Sergeev // Geology of ore deposits. - 2011. V. 53. - Iss. 1. - P. 27-57.

24. P-T-X conditions on the genesis of orogenic $\mathrm{Au}(\mathrm{As}, \mathrm{Bi}, \mathrm{Ag})$ deposit in metasedimentary rocks of the Buracao Area, Arai Group, Brasilia Fold Belt, Brasil / G.L.C. Pires, C. Renac, E.M. Bongiolo, R. Neumann, A. Barats // Ore Geology Reviews. - 2019. V. $105 .-$ P. $163-182$.
25. Noble metals in black shales of the Sukhoi Log gold deposit (East Siberia): evidence from scintillation arc atomic-emission spectrometry / I.E. Vasil'eva, E.V. Shabanova, E.M. Goryacheva, 0.T. Sotskaya, V.A. Labusov, A.A. Dzyuba, 0.A. Nekludov // Rassian Geology and Geophysics. - 2018. - V. 59. - № 8. P. 997-1009.

26. The gold ore deposit Bakyrchic and views on the formation of the mineral deposits in black shale strata / Z. Umarbekova, R. Seltmann, K. Dyussembaeva, M. Kokkuzova // Proceedings of the $17^{\text {th }}$ International Multidisciplinary Scientific GeoConference SGEM. - 2017. - V. 17. - Iss. 11. - P. 1111-1118. DOI: $10.5593 /$ sgem 2017/11/S04.142 (www.sgem.org.)

27. A black shale protolith for gold-tellurium mineralization in the Dalradian Supergroup (Neoproterozoic) of Britain and Ireland / J. Parnell, M. Perez, J. Armstrong, L. Bullock, J. Feldmann and A.J. Boyce // Applied Earth Science. - 2017. - V. 126. - № 4. P. 161-175. URL: https://doi.org/10.1080/03717453.2017.1404682 (дата обращения: 20.04.2019).

28. Augustin J., Gaboury D. Multi-stage and multi-sourced fluid and gold in the formation of orogenic gold deposits in the world-class Mana district of Burcina Faso-Revealed by LA-ICP-MS analysis of pyrites and arsenopyrites // Ore Geology Reviews. - 2019. V. $104 .-$ P. $495-521$

29. Damdinov B.B., Damdinova L.B. Zun-Ospa gold deposit, Eastern Sayan: Geology, ore composition and genesis / Geology of ore deposits. - 2018. - V. 60. - Iss. 3. - P. 241-264.

30. Nature and source of the ore-forming fluids associated with orogenic gold deposits in the Dharwar craton / B. Mishra, K.L. Pruseth, P. Nazarika, S.S. Chinnasamy // Geoscience Frontiers. 2018. - V. 9. - Iss. 3. - P. 715-726.

31. Formation of epizonal gold mineralization within the Latimojong metamorphic complex, Sulawesi, Indonesia: Evidence from mineralogy, fluid inclusions and Raman spectroscopy / A.Y.A. Hakim, F. Melcher, W. Prochaska, R. Bakker, G. Rantitsch // Ore Geology reviews. - 2018. - V. 97. - P. 88-108.

32. Kondrat'eva L.A., Anisimova G.S., Zaitsev A.I. The Zaderzhninskoe gold deposit: mineral composition, fluid inclusions and age (South Verkhoyansk region) // Russian Geology and Geophysics. - 2018. - V. 59. - Iss. 10. - P. 1288-1300.

33. Local and regional mass transfer during trusting, veining and boudinage in the genesis of the giant shale-hosted Paracatu gold deposit, Minas Gerais, Brazil / N.H.S. Oliver, B. Thomson, F.H. Freitas-Silva, R.J. Holcombe, B. Rusk, B.S. Almeida, K. Faure, G.R. Davidson, E.L. Esper, P.J. Guimaraes, M.A. Dardenne // Economic Geology. - 2015. - V. 110. - Iss. 7. P. 1803-1834.

34. Chemical evolution of pyrite at the Kopylovsky and Kavkaz black shale-hosted gold deposits, Bodaybo district, Russia: Evidence from EPMA and La-ICP-MS data / E.E. Palenova, E.V. Belogub, O.Y. Plotinskaya, K.A. Novoselov, V.V. Maslennikov, V.A. Kotlyarov, I.A. Blinov, A.A. Kuzmenko, I.G. Griboedova // Geology of ore deposits. - 2015. - V. 57. - Iss. 1. - P. 64-84.

35. Gold concentrations in metamorphic fluids: a LA-ICP-MS study of fluid inclusions from the Alpine orogenic belt / K. Rauchenstein-Martinek, T. Wagner, M. Walle, C.A. Heinrich // Chemical Geology. - 2014. - V. 385. - P. 70-83.

36. Age, origin and significance of nodular sulfides in $2680 \mathrm{Ma}$ carbonaceous black shale of the Eastern Goldfields Superterrane, Yilgarn Craton, Western Australia / J.A. Steadman, R.R. Large, S. Meffre, S.W. Bull // Precambrian Research. - 2013. - V. 230. P. 227-247.

37. Large R.R., Maslennikov V.V. A carbonaceous sedimentary source-rock model for carlin-type and orogenic gold deposits // Economic Geology. - 2011. - V. 106. - Iss. 3. P. 331-358.

38. Этапы формирования крупномасштабной благороднометальной минерализации месторождения Сухой Лог (Восточная Си- 
бирь): результаты изотопно-геохронологического изучения Н.П. Лаверов, И.В. Чернышов, А.В. Чугаев, Э.Д. Баирова, Ю.В. Гольцман, В.В. Дистлер, М.А. Юдовская // Доклады PAH. - 2007. - T. 415. - № 2. - C. 236-241.

39. Кучеренко И.В., Грибанов А.П. Взаимоотношения дайковых образований с золоторудными кварцевыми жилами в Берикульском рудном поле // Известия Томского политехнического института. - 1968. - Т. 134. - С. 153-158.

40. Кучеренко И.В. Пространственно-временнь'е и петрохимические критерии связи образования золотого оруденения с глубинным магматизмом // Известия АН СССР. Серия геологическая. -1990 - № 10. - С. 78-91.

41. Кучеренко И.В. Металлогения золота: приложение к мезотермальным месторождениям, образованным в несланцевом и черносланцевом субстрате горно-складчатых сооружений Южной Сибири / / Современные проблемы геологии и разведки полезных ископаемых: Материалы Международной конф., посвящ. 80-летию основания в Томском политехническом университете первой в азиатской части России кафедры «Разведочное дело». - Томск, 5-8 октября 2010 г. - Томск: Изд-во ТПУ, 2010. - С. 241-256.

42. Кучеренко И.В. Петрология гидротермального метасоматизма долеритов внутрирудных даек мезотермальных месторождений золота. Часть 1. Кедровское месторождение (Северное Забайкалье) // Известия Томского политехнического университета. - 2014. - Т. 325. - № 1. - С. 155-165.

43. Кучеренко И.В. Петрология гидротермального метасоматизма долеритов внутрирудных даек мезотермальных месторождений золота. Часть 2. Месторождение Зун-Холба (Восточный Саян) // Известия Томского политехнического университета. 2015. - T. 326. - № 1. - С. 73-86.

44. Этапы формирования Бодайбинского золоторудного района / И.К. Рундквист, В.А. Бобров, Т.Н. Смирнова, М.Ю. Смирнов,
М.Ю. Данилова, А.А. Ащеулов // Геология рудных месторождений. - 1992. - Т. 34. - № 6. - С. 3-15.

45. Шер С.Д. Жильные изверженные породы основного состава в бассейне р. Бодайбо и их соотношения с кварцевыми жилами // Труды Центрального научно-исследовательского геологоразведочного института. - 1959. - Вып. 4. - С. 104-114.

46. Кондратенко А.К., Шер С.Д. Метасоматические изменения жильных пород в Ленской золотоносной области и их поисковое значение с точки зрения золотоносности // Вопросы геологии месторождений золота и золотоносных районов. - М.: ЦНИГРИ, 1968. - С. 312-314.

47. Синцов А.В. Роль Кадали-Сухоложского разлома в размещении золотого оруденения (Ленский золотоносный район) // Доклады АН СССР. - 1974. - Т. 218. - № 4. - С. 916-918.

48. Поспелов Г.Л. Геологические предпосылки к физике рудоконтролирующих флюидопроводников // Геология и геофизика. 1963. - № 3. - С. 18-19.

49. Рундквист Д.В. 0 влиянии распределения температур горных пород на процессы метасоматического гидротермального минералообразования // Записки Всесоюзного минералогического общества. - 1966. - Ч. 95. - Вып. 5. - С. 509-525.

50. Гаврилов А.М., Кряжев С.Г. Минералого-геохимические особенности руд месторождения Сухой Лог // Разведка и охрана недр. - 2008. - № 8. - С. 3-16.

51. Петролого-геохимические черты околорудного метасоматизма в золоторудном месторождении Сухой Лог (Ленский район). Ч. 2. Петрология околорудного метасоматизма / И.В. Кучеренко, Р.Ю. Гаврилов, В.Г. Мартыненко, А.В. Верхозин // Известия Томского политехнического университета. Науки о земле. - 2012. - Т. 320. - № 1. - С. 28-37.

Поступила 29.04.2019 2.

\section{Информация об авторах}

Кучеренко И.В., доктор геолого-минералогических наук, профессор, Национальный исследовательский Томский политехнический университет. 


\title{
ORE GEOLOGY PROBLEMS AND THE HUMAN FACTOR. PART 4. METAMORPHISM AND MESOTHERMAL OREFORMATION
}

\author{
Igor V. Kucherenko, \\ kivr@tpu.ru \\ National Research Tomsk Polytechnic University, \\ 30, Lenin Avenue, Tomsk, 634050, Russia.
}

The relevance of the research. The conditions of the known large mesothermal gold deposits formation into black shales states of different age form the subject of animated discussion which often acquires the signs of substitute and probably therefore the endless one as a result of exception by concrete author or author's group of the facts important for the problem solution but which don't fit in database of developing by him/them ideas, from the consideration, discussion, generalization.

The main aim of the research. To obtain the correct results required for deepening the hydrothermal ore formation theory and developing, improving the effective forecast-search criteria of the deposits it is necessary to remove this negative manifestation of the human factor and return the discussion in normal course by means of including in scientific expression of "handy» and "non handy» facts in reconstruction of ore formation.

The methods of the research. The author has analyzed the database proposed long ago and recently for substantiation of the metamorphic-hydrothermal and others hypotheses of mesothermal gold deposits formation into black shales strates. The paper introduces the author's materials, including the analytic data - the results of the full chemical silicate analysis (wet) of rocks, atomic-absorption analysis of the content of gold, silver, mercury into rocks, petrochemic balance calculations of the between-zoning migration of chemical elements into near-ore metasomatic haloes, mathematical computing of the analyses results (content oregenous elements).

The results of the research. The author made the conclusion on geology-genetic uniformity of mesothermal gold deposits formed into crystalline substratum and black shales. The following facts: 1) control of gold deposits by deep faults; 2) similar geologic age of early plutons, massifs of palingenetic granitoids with large accompanying dikes of average-soured rocks and late dikes of the moderatelyalkaline dolerites, dolerites, leucodolerites of tillore, insideore, afterore generations, including transformed into hightemperature biotite-amphibole hornblende metasomatites of insideore dikes-fluidconductors, and ores; 3) authentic mineral-petrochemic zoning of the near-ore metasomatic haloes in both substratum, formed in conditions of potassium-sulphurously-carbon-dioxidic metasomatism of propilite-beresitic type with entrance into haloes of potassium, restoring sulphur, carbon dioxide, removal of sodium and partly silicium; 4) inheritance by the nearore metasomatites of the petrochemic type insidedoleritic metasomatism and contrasting anomalies of the femic (Mg, Fe, P, Ti) elements; 5) isotopic relations of sulphides sulphur and carbonates carbon of ores and nearore metasomatites meeting the meteoritic standard (the mantle), prove the conclusion. The enumerated facts eliminate the participation of metamorphism in ore formation.

In Lensk region, as well as in others goldore regions of mountain-folded Siberian craton frame, mesothermal gold deposits are formed into antidromic granite-diorite-dolerite fluid-ore-magmatic complexes composition at late basic stage of their function, and insideore dikes-fluid conductors of moderately-alkaline dolerites are the link between basic hearthes of mantle - the sources of gold-bearing solutions, and deposits in the crust.

Paper structure. The $3^{\text {rd }}$ part of the paper has the following sections: subject of the problems and the formulation of the task; mineralpetrochemic zoning of the nearore propilitic-beresitic type metasomatic haloes in mesothermal gold deposits formed into crystalline substratum and black shales series; mineral-petrochemic zoning of the gold deposit Sukhoi Log nearore metasomatic haloe. In the $4^{\text {th }}$ part of the paper there are the following sections: the distribution of oregenous elements into nearore expanse of the mesothermal gold deposits formed into crystalline substratum and black shales series; the discussion of the results and conclusion.

Key words:

Mesothermal gold deposits, crystalline substratum, black shales, magmatism, metamorphism, ore formation, human factor.

\section{REFERENCES}

1. Sher S.D. Okolorudnye izmeneniya, soputstvuyushchie zolotokvarczevym zhilam v Lenskom zolotonosnom rayone [Near-ore changings accompanying to gold-quartz veins in Lenskii auriferous]. Metasomaticheskie izmeneniya bokovykh porod i ikh rol $v$ rudoobrazovanii [Metasomatic alterations of the lateral rocks and their lines in ore formation]. Moscow, Nedra Publ., 1966. pp. 282-291.

2. Konovalov I.V. Okolorudnaya zonalnost odnogo zolotorudnogo mestorozhdeniya (Lenskiy rayon) [Near-ore zoning of one goldore deposit (Lenskii region)]. Geologiya i geofizika, 1973, no. 1, pp. 123-125.

3. Shmotov A.P. Tektonicheskie deformatsii i sopryazhennye s nimi gidrotermalno-metasomaticheskie preobrazovaniya vmeshchayushchikh porod (Lenskiy zolotonosny rayon) [Tectonic deformations and related to them hydrothermal metosomatic alterations of the containing rocks (Lenskii auriferous region)]. Papers of AC SSSR, 1974, vol. 218, no. 1, pp. 178-181.
4. Sharov V.N., Shmotov A.P., Konovalov I.V. Metasomaticheskaya zonalnost $i$ svyaz s ney orudeneniya [Metasomatic zoning and mineralization related to it]. Novosibirsk, Nauka Publ., 1978. $103 \mathrm{p}$.

5. Buryak V.A., Letnikov F.A. 0 roli protsessov regionalnogo metamorfizma i ultrametamorfizma v razvitii zolotogo orudeneniya [0n the influence of regional metamorphism and ultrametamorphism in ore-grade gold mineralization]. Voprosy geologii mestorozhdeniy zolota [The problems of the gold deposits geology]. Tomsk, Tomsk University Publ., 1970. pp. 19-24.

6. Buryak V.A. Metamorfizm i rudoobrazovanie [Metamorphism and ore-formation]. Moscow, Nedra Publ., 1982. 256 p.

7. Rusinov V.L., Rusinova 0.V., Kryazhev S.G. Okolorudny metasomatizm terrigennykh uglerodistykh porod v Lenskom zolotorudnom rayone [Near ore metasomatism of the terrigenous carbonaceous rocks in Lenskii auriferous region]. Geologiya rudnykh mestorozhdeniy, 2008, vol. 50, no. 1, pp. 3-46. In Rus.

8. Kucherenko I.V. Ore geology problems and the human factor. Part 1. Mineral-petrochemic zoning of the near-veins metasoma- 
tic aureoles in the mesothermal gold deposits: theory, experiment, nature. Bulletin of the Tomsk Polytechnic University. Geo Assets Engineering, 2017, vol. 328, no. 7, pp. 105-118. In Rus.

9. Kucherenko I.V. Ore geology problems and the human factor. Part 2. Magmatism and mesothermal ore-formation. Bulletin of the Tomsk Polytechnic University. Geo Assets Engineering, 2018, vol. 329, no. 6, pp. 148-170. In Rus.

10. Laverov N.P., Distler V.V., Safonov Yu.G., Chernyshov I.V., Yudovskaya M.A., Mitrofanov G.L., Nemerov V.K. Rudoobrazuyushchaya sistema zoloto-platinovogo mestorozhdeniya Sukhoy Log [Oreformating system of the gold-platinum deposit Sukhoi Log]. Metallogeniya, neftegazonosnost i geodinamika Severo-Aziatskogo kratona i orogennykh poyasov ego obramleniya. Materialy II Vserossiyskogo metallogenicheskogo soveshhaniya [Metallogeny, oil-gas-containing and geodynamics of North-Asian craton and orogenic belts it frame. Materials of II Allrussian Metallogenic conference]. Irkutsk, 25-28 August 1998. pp. 296.

11. Kryazhev S.G. Geneticheskie modeli i kriterii prognoza zolotorudnykh mestorozhdeniy $v$ uglerodisto-terrigennykh kompleksakh. Avtoreferat Dis. Dokt. nauk [The genetic models and forecast criteria of the gold-ore deposits into carbonaceous-terrigenous complexes. Dr. Diss. Abstract]. Moscow, 2017. 52 p.

12. Laverov N.P., Prokofev V.Yu., Distler V.V., Yudovskaya M.A., Spiridonov A.M., Grebenshchikova V.I., Matel N.L. Novye dannye ob usloviyakh rudootlozheniya i sostave rudoobrazuyushchikh flyuidov zoloto-platinovogo mestorozhdeniya Sukhoy Log [New data on the conditions of ore-formation and ore-forming fluids composition of Sukhoi Log gold-platinum deposit]. Papers of RAC, 2000, vol. 371, no. 1, pp. 88-92. In Rus.

13. Distler V.V., Mitrofanov G.L., Nemerov V.K., Kovalenker V.A., Mokhov A.V., Semeykina L.K., Yudovskaya M.A. Formy nakhozhdeniya metallov platinovoy gruppy $i$ ikh genezis v zolotorudnom mestorozhdenii Sukhoy Log (Rossiya) [Forms of participation of the platinum group metals and their genesis in gold-ore deposit Sukhoi Log (Russia)]. Geologiya rudnykh mestorozhdeniy, 1996, vol. 38, no. 6, pp. 467-484.

14. Marakushev A.A., Rusinov V.L. Nature of the gold-bearing of the carbonaceous series. Papers of RAC, 2005, vol. 401, no. 4, pp. 515-520. In Rus.

15. Rusinov V.L., Rusinova O.V., Borisovskiy S.E., Alysheva E.I. The composition of the Sukhoi Log gold-ore deposit metasomatic minerals as criterion of the genetic connection with subsilicic-ultrabasitic magmatism. Papers of RAC, 2005, vol. 405, no. 5, pp. 661-665. In Rus.

16. Ozerova N.A. Rtut i endogennoe rudoobrazovanie [Mercury and endogenous ore formation]. Moscow, Nauka Publ., 1986. 155 p.

17. Stepanov V.A., Moiseenko V.G. Geologiya zolota, serebra i rtuti [Mercury and endogenous ore formation]. Vladivostok, Dalnauka Publ., 1993. $228 \mathrm{p}$.

18. Molchanov V.P., Khanchuk A.I., Medvedev E.I., Plyusnina L.P. Unique association of natural amalgam gold, cinnabar, native metals and carbides of Fadeevskoi ore-deposit knot, Seaside. Papers of RAC, 2008, vol. 422, no. 4, pp. 536-538. In Rus.

19. Selvaraja Vikraman, Fiorentini M.L., Jeon Heejin, Savard D.D., Laflamme C.K., Guagliardo P., Caruso S., Bui Thi-Hao. Evidence of local sourcing of sulphur and gold in an Archaean sedimenthosted gold deposit. Ore Geology Reviews, 2017, vol. 89, pp. 909-930.

20. Wang D., Sheng Y., Mathur R., Jiang J., Shang S., Sheng J., $\mathrm{Yu}$ M. Multiple mineralization events in the Zhaxikand Sb-Pb$\mathrm{Zn}-\mathrm{Ag}$ deposit and their relationship with the geodynamic evolution in the North Himalayan Metallogenic Belt, South Tibet. Ore geology Reviews, 2019, vol. 105, pp. 201-215.

21. Khanchuk A.I., Plyusnina L.P., Nikitenko E.M. The Noble Metal Distribution in the black shales of the Degdekan Gold deposit in Northeast Russia. Russian journal of Pacific Geology, 2011, vol. 5 , no. 2, pp. 89-96.
22. Vasilyeva I.E., Shabanova E.V., Razvozzaeva E.A. Noble metals in the insoluble carbonaceous substance of black shales and ores: Direct atomic emission data. Geochemistry International, 2012, vol. 50, no. 9, pp. 771-776.

23. Yudovskaya M.A., Distler V.V., Rodionov N.V., Mokhov A.V., Antonov A.V., Sergeev S.A. Relationship between metamorphism and ore formation at the Sukhoi Log gold deposit hosted in black slates from the data of U-Th-Pb isotopic SHRIMP-dating of accessory minerals. Geology of ore deposits, 2011, vol. 53, Iss. 1, pp. 27-57.

24. Pires G.L.C., Renac C., Bongiolo E.M., Neumann R., Barats A. $\mathrm{P}-\mathrm{T}-\mathrm{X}$ conditions on the genesis of orogenic $\mathrm{Au}(\mathrm{As}, \mathrm{Bi}, \mathrm{Ag})$ deposit in metasedimentary rocks of the Buracao Area, Arai Group, Brasilia Fold Belt, Brasil. Ore Geology Reviews, 2019, vol. 105, pp. 163-182.

25. Vasileva I.E., Shabanova E.V., Goryacheva E.M., Sotskaya 0.T., Labusov V.A., Dzyuba A.A., Nekludov 0.A. Noble metals in black shales of the Sukhoi Log gold deposit (East Siberia): evidence from scintillation arc atomic-emission spectrometry. Rassian Geology and Geophysics, 2018, vol. 59, no. 8, pp. 997-1009.

26. Umarbekova Z., Seltmann R., Dyussembaeva K., Kokkuzova M. The gold ore deposit Bakyrchic and views on the formation of the mineral deposits in black shale strata. Proc. of the $17^{\text {th }}$ International Multidisciplinary Scientific GeoConference SGEM, 2017. vol. 17 , iss. 11, pp. 1111-1118. DOI: 10.5593/sgem2017/11/ S04.142 (www.sgem.org.)

27. Parnell J., Perez M., Armstrong J., Bullock L., Feldmann J., Boyce A.J. A black shale protolith for gold-tellurium mineralization in the Dalradian Supergroup (Neoproterozoic) of Britain and Ireland. Applied Earth Science, 2017, vol. 126, no. 4, pp. 161-175. Available at: https://doi.org/10.1080/03717453.2017.1404682 (accessed 20 April 2019).

28. Augustin J., Gaboury D. Multi-stage and multi-sourced fluid and gold in the formation of orogenic gold deposits in the world-class Mana district of Burcina Faso-Revealed by LA-ICP-MS analysis of pyrites and arsenopyrites. Ore Geology Reviews, 2019, vol. 104, pp. $495-521$.

29. Damdinov B.B., Damdinova L.B. Zun-Ospa gold deposit, Eastern Sayan: Geology, ore composition and genesis. Geology of ore deposits, 2018, vol. 60, iss. 3, pp. 241-264.

30. Mishra B., Pruseth K.L., Nazarika P., Chinnasamy S.S. Nature and source of the ore-forming fluids associated with orogenic gold deposits in the Dharwar craton. Geoscience Frontiers, 2018, vol. 9, Iss. 3, pp. 715-726.

31. Hakim A.Y.A., Melcher F., Prochaska W., Bakker R., Rantitsch G. Formation of epizonal gold mineralization within the Latimojong metamorphic complex, Sulawesi, Indonesia: Evidence from mineralogy, fluid inclusions and Raman spectroscopy. Ore Geology reviews, 2018, vol. 97, pp. 88-108.

32. Kondrateva L.A., Anisimova G.S., Zaitsev A.I. The Zaderzhninskoe gold deposit: mineral composition, fluid inclusions and age (South Verkhoyansk region). Russian Geology and Geophysics, 2018, vol. 59, Iss. 10, pp. 1288-1300.

33. Oliver N.H.S., Thomson B., Freitas-Silva F.H., Holcombe R.J., Rusk B., Almeida B.S., Faure K., Davidson G.R., Esper E.L., Guimaraes P.J., Dardenne M.A. Local and regional mass transfer during trusting, veining and boudinage in the genesis of the giant shale-hosted Paracatu gold deposit, Minas Gerais, Brazil. Economic Geology, 2015, vol. 110, Iss. 7, pp. 1803-1834.

34. Palenova E.E., Belogub E.V., Plotinskaya 0.Y., Novoselov K.A., Maslennikov V.V., Kotlyarov V.A., Blinov I.A., Kuzmenko A.A., Griboedova I.G. Chemical evolution of pyrite at the Kopylovsky and Kavkaz black shale-hosted gold deposits, Bodaybo district, Russia: Evidence from EPMA and La-ICP-MS data. Geology of ore deposits, 2015, vol. 57, Iss. 1, pp. 64-84.

35. Rauchenstein-Martinek K., Wagner T., Walle M., Heinrich C.A. Gold concentrations in metamorphic fluids: a LA-ICP-MS study 
of fluid inclusions from the Alpine orogenic belt. Chemical Geology, 2014, vol. 385, pp. 70-83.

36. Steadman J.A., Large R.R., Meffre S., Bull S.W. Age, origin and significance of nodular sulfides in $2680 \mathrm{Ma}$ carbonaceous black shale of the Eastern Goldfields Superterrane, Yilgarn Craton, Western Australia. Precambrian Research, 2013, vol. 230, pp. 227-247.

37. Large R.R., Maslennikov V.V. A carbonaceous sedimentary source-rock model for carbin-type and orogenic gold deposits. Economic Geology, 2011, vol. 106, Iss. 3, pp. 331-358.

38. Laverov N.P., Chernyshov I.V., Chugaev A.V., Bairova E.D., Goltsman Yu.V., Distler V.V., Yudovskaya M.A. The stages of formation of the large-scale noble-metal mineralization into Sukhoi Log deposit (Eastern Siberia): isotope-geochronological study result. Papers of RAC, 2007, vol. 415, no. 2, pp. 236-241. In Rus.

39. Kucherenko I.V., Gribanov A.P. Vzaimootnosheniya daykovykh obrazovaniy s zolotorudnymi kvartsevymi zhilami v Berikulskom rudnom pole [Interrelationships of dykes with gold-ore quartz veins in Bericul deposit]. Bulletin of the Tomsk Polytechnic Institute, 1968, vol. 134, pp. 153-158.

40. Kucherenko I.V. Prostranstvenno-vremennye i petrokhimicheskie kriterii svyazi obrazovaniya zolotogo orudeneniya s glubinnym magmatizmom [Spatially-temporary and petrochemic criteria of gold mineral formation relation to plutonic magmatism]. Izvestiya AN SSSR. Seriya geologicheskaya, 1990, no. 10, pp. 78-91.

41. Kucherenko I.V. Metallogeniya zolota: prilozhenie k mezotermalnym mestorozhdeniyam, obrazovannym v neslantsevom i chernoslantsevom substrate gorno-skladchatykh sooruzheniy Yuzhnoy Sibiri [Metallogeny of gold: the supplement to mesothermal deposits formed into nonshales and black shales substratum of the mauntin-folded structures of Southern Siberia]. Sovremennye problemy geologii i razvedki poleznykh iskopaemykh: Materialy Mezhdunarodnoy konferentsii, posvyashchennoy 80-letiyu osnovaniya $v$ Tomskom politekhnicheskom universitete pervoy $v$ aziatskoy chasti Rossii kafedry "Razvedochnoe delo» [Contemporary problems of geology and exploration minerals. Materials of International conference]. Tomsk, 5-8 October 2010. pp. 241-256.

42. Kucherenko I.V. Petrology of hydrothermal metasomatism of intra-ore dolerite dikes of mesothermal gold deposits. Part 1. Kedrovskoe deposit (Northern Transbaikalye). Bulletin of the Tomsk Polytechnic University, 2014, vol. 325, no 1, pp. 155-165. In Rus.

43. Kucherenko I.V. Petrology of hydrothermal metasomatism of intra-ore dolerite dikes of mesothermal gold deposits. Part 2. Zun

\section{Information about the authors}

Igor V. Kucherenko, Dr. Sc., professor, National Research Tomsk Polytechnic University.
Kholba deposit (Eastern Sayan). Bulletin of the Tomsk Polytechnic University, 2015, vol. 326, no. 1, pp. 73-86. In Rus.

44. Rundkvist I.K., Bobrov V.A., Smirnova T.N., Smirnov M.Yu., Danilova M.Yu., Ashheulov A.A. Etapy formirovaniya Bodaybinskogo zolotorudnogo rayona [The stages of Bodaibo gold-ore region formation]. Geologiya rudnykh mestorozhdeniy, 1992, vol. 34 , no. 6, pp. 3-15.

45. Sher S.D. Zhilnye izverzhennye porody osnovnogo sostava v basseyne r. Bodaybo i ikh sootnosheniya s kvartsevymi zhilami [The vein igneous rock of the basic composition in river Bodaibo reservoir and their correlation with quartz vein]. Trudy Tsentralnogo nauchno-issledovatelskogo geologorazvedochnogo instituta, 1959, Iss. 4, pp. 104-114.

46. Kondratenko A.K., Sher S.D. Metasomaticheskie izmeneniya zhilnykh porod v Lenskoy zolotonosnoy oblasti i ikh poiskovoe znachenie s tochki zreniya zolotonosnosti [Metasomatic alterations of veins rocks in Lensky auric region and their search meaning with point of view of gold-bearing]. Voprosy geologii mestorozhdeniy zolota i zolotonosnykh rayonou [Issues of geology of the gold deposits and auriferous regions]. Moscow, CzNIGRI Publ., 1968. pp. 312-314.

47. Sintsov A.V. Rol Kadali-Sukholozhskogo razloma v razmeshchenii zolotogo orudeneniya (Lenskiy zolotonosny rayon) [Part of Kadali-Sukhoii Log fault in gold mineralization localization (Lenskii gold-containing region)]. Papers of AS SSSR, 1974, vol. 218, no. 4, pp. 916-918.

48. Pospelov G.L. Geologicheskie predposylki k fizike rudokontroliruyushchikh flyuidoprovodnikov [Geologic preconditions to physics of ore-controling fluidostringers]. Geologiya i geofizika, 1963, no. 3, pp. 18-19.

49. Rundkvist D.V. 0 vliyanii raspredeleniya temperatur gornykh porod na protsessy metasomaticheskogo gidrotermalnogo mineraloobrazovaniya [On the influence of rocks temperature distribution on metasomatic hydrothermal mineral formation]. Zapiski Vsesoyuznogo mineralogicheskogo obshhestva, 1966, Ch. 95, Iss. 5, pp. 509-525.

50. Gavrilov A.M., Kryazhev S.G. Mineral-geochemic ores peculiarities of the deposit Sukhoi Log. Razvedka i okhrana nedr, 2008, no. 8, pp. 3-16. In Rus.

51. Kucherenko I.V., Gavrilov R.Yu., Martynenko V.G., Verkhozin A.V. Petrologic geochemic features of the near ore metasomatism in gold-ore deposit Sukhoi Log (Lenskii region). Part 2. Petrology of near-ore metasomatism. Bulletin of the Tomsk Polytechnic University, 2012, vol. 320, no. 1, pp. 28-37. In Rus.

Received: 29 April 2019. 